\title{
Üstbilişsel Yazma Stratejileri Eğitiminin Yazma Becerisine ve Yazmaya Yönelik Tutuma Etkisi ${ }^{1 *}$
}

\author{
Teymur EROL \\ Öğr. Gör. Dr., Kahramanmaraş Sütçü İmam Üniversitesi, \\ Rektörlük, Türk Dili Bölümü \\ erolteymur@gmail.com \\ Orcid ID: https://orcid.org/0000-0003-1738-0858 \\ Hasan KAVRUK \\ Prof. Dr., İnönü Üniversitesi, \\ Eğitim Fakültesi, Türkçe ve Sosyal Bilimler Eğitimi Bölümü, \\ Türkçe Eğitimi Anabilim Dalı \\ hasan.kavruk@inonu.edu.tr \\ Orcid ID: https://orcid.org/0000-0001-6352-4985
}

\begin{abstract}
Öz
$\mathrm{Bu}$ araştırmanın amacı; üstbilişsel yazma stratejilerine dayalı eğitimin yedinci sınıf öğrencilerinin üstbilişsel yazma stratejileri farkındalıklarına, yazma becerilerine ve yazmaya ilişkin tutumuna etkisini incelemektir. Araştırmada karma yöntemlerden açıklayıcı sıralı desen kullanılmıştır. Araştırmanın nicel bölümünde, gerçek deneysel desenlerden biri olan ön test ve son test kontrol gruplu seçkisiz desenden; nitel bölümünde yarı yapılandırılmış görüşme tekniğinden yararlanılmıştır. Yedinci sınıf öğrencilerinden seçilen çalışma grubu seçkisiz atama yöntemiyle 30'u deney, 30'u kontrol olmak üzere 60 öğrenciden oluşmaktadır. Araştırma kapsamında, deney grubundaki öğrencilere 10 hafta boyunca üstbilişsel yazma stratejileri eğitimi verilmiş, kontrol grubunda ise MEB'in mevcut öğretim programı doğrultusunda eğitim yapılmıştır. Araştırmanın nicel verileri duruma göre parametrik ve parametrik olmayan testlerle analiz edilmiştir. Yarı yapılandırılmış görüşme formlarıyla elde edilen nitel veriler betimsel analiz yöntemiyle incelenmiştir. Araştırma sonuçlarına göre; üstbilişsel yazma stratejileri eğitimi, deney grubu öğrencilerinin yazmaya yönelik olumlu tutum geliştirmesinde, üstbilişsel yazma

\footnotetext{
${ }^{1}$ Makale Geliş/Kabul Tarihi: 20.04.2021 / 27.07.2021

* Bu makale "Üstbilişsel Yazma Stratejileri Eğitiminin Yazma Becerisine ve Yazmaya Yönelik Tutuma Etkisi” başlıklı doktora tezinden üretilmiştir.

Künye Bilgisi: Erol, T. Ve Kavruk, H. (2021). Bir romancının gözüyle Ortadoğu'yu şekillendiren milletler üstbilişsel yazma stratejileri eğitiminin yazma becerisine ve yazmaya yönelik tutuma etkisi. Kahramanmaraşs Sütçü İmam Üniversitesi Sosyal Bilimler Dergisi, 18(2), 741-771. DOI: 10.33437/ksusbd.923783
} 
stratejileri farkındalıklarının ve yazma becerisi başarı düzeyinin artmasında etkili olmuştur. Deney grubundaki öğrenciler, üstbilişsel yazma stratejileri eğitimi ile ilgili genel olarak olumlu görüş bildirmiştir. Uygulanan deneysel işlem, öğrencilerin yazma becerisine yönelik düşünce ve tutumu ile yazıya başlama duygusunu büyük ölçüde olumlu etkilemiştir. Verilen eğitim, deney grubundaki öğrencilerin yazma alışkanlıklarının artmasına ve yazma kaygılarının azalmasına katkı sağlamıştır.

Anahtar Kelimeler: Üstbiliş, Üstbilişsel Yazma Stratejileri, Strateji Eğitimi, Yazma Becerisi, Yazmaya Yönelik Tutum.

\title{
The Effect of Metacognitive Writing Strategies on Writing Skills and Writing Attitudes
}

\begin{abstract}
The purpose of this research is to investigate the effects of education based on metacognitive writing strategies on seventh grade students' awareness of metacognitive writing strategies, their writing skills and their attitudes towards writing. Explanatory sequential design, one of the mixed methods, was used in the study. In the quantitative part of the research, one of the real experimental designs, the pretest and posttest random design with control group; in the qualitative part, semi-structured interview technique was used. The study group selected from the seventh grade students consists of 60 students, 30 of which are experimental and 30 are control, by random assignment method. Within the scope of the study, metacognitive writing strategies training was given to the students in the experimental group for 10 weeks, while the control group was trained in line with the current curriculum of the Ministry of National Education. The quantitative data of the study were analyzed with parametric and non-parametric tests, depending on the situation. Qualitative data obtained with semi-structured interview forms were analyzed by descriptive analysis method. According to the results of the research, metacognitive writing strategies training was effective in developing positive attitudes towards writing in the experimental group students, increasing their awareness of metacognitive writing strategies and the success level of writing skills. Students in the experimental group generally reported positive opinions about metacognitive writing strategies training. The experimental procedure applied greatly positively affected the students' thoughts and attitudes towards writing skills and their sense of starting to write. The training provided contributed to the increase in the writing habits of the students in the experimental group and the reduction of their writing anxiety.
\end{abstract}


Keywords: Metacognition, Metacognitive Writing Strategies, Strategy Education, Writing Skill, Writing Attitude.

\section{GÍRIŞ}

Yazma becerisi, tarihsel süreç içerisinde ilkel bir iletişim aracından karmaşık bir beceriye dönüşmüştür. İnsanoğlu bu dönüşüm sürecinde yazıyı kullanarak birikimini kalıcı hale getirebilmiştir (Şimşek ve Erdem, 2021: 269). Doğası gereği disiplinler arası alanlardan yoğun biçimde beslenen dil eğitimi, ortaya çıkan yeni strateji, yöntem ve tekniklere duyarsız kalmamıştır. Başta eğitim bilim olmak üzere, eğitim ve öğrenme psikolojisi, bilişsel psikoloji gibi farklı alanlarda yürütülen çalışmalar, temel dil becerileri eğitiminin yeniden ele alınmasını ve günün ihtiyaçları doğrultusunda güncellenmesini sağlamıştır. Böylece geleneksel kalıplar terk edilmiş, diğer temel dil becerileri gibi, yazma becerisine ait teorik birikimler, pedagojik veriler 1 şı̆̆ında yeniden değerlendirilmiştir. Geçmişte çok az kesim tarafından bilinip kullanılan yazı, zamanla en önemli devlet politikalarından biri hâline dönüşmüş, okullar ve çeşitli kurumlar aracılığıyla geniş halk kitlelerine öğretilmeye çalışılmıştır (Aydın ve Kaya, 2021: 181).

Yazma becerisi için literatürde üç ana yaklaşımdan söz edilmektedir: Metni biçim, kelime hazinesi, dil bilgisi vb. açılardan inceleyen ürün/metin odaklı yaklaşım; metnin yazarına ve metinleştirme süreçlerine odaklanan süreç/bilişsel odaklı yaklaşım ile okurun yazma üzerindeki rolünü ve yazarın metin oluştururken hedef kitleyle etkileşimini dikkate alan okur/tür odaklı yaklaşım (Hyland, 2016: 3-4).

Geleneksel yaklaşım olarak adlandırılan ve önceden öğretmen tarafından belirlenmiş birtakım kalıp ve kurallara göre gerçekleştirilen yazma üretimi "ürün odaklı yazma" olarak adlandırılmaktadır (Zamel, 1982: 195). Metinlerin bağlam, yazar veya okuyucudan bağımsız olarak incelenmesi gereken özerk nesneler olduğu düşüncesi, yaklaşımın temelini oluşturmakta ve metinler bağlamından kopuk özerk nesneler olarak görülmektedir (Hyland, 2016: 5). Bu anlayış; yapısalcılıktan, Chomsky'nin üretici dönüşümsel dil bilgisi kuramından ve geleneksel anlama modellerinden biri olan parçadan bütüne teorisinden miras olarak kalmıştır.

1900'lü yılların ortalarına kadar tüm dünyada hâkim olan bu yaklaşımda yazı, mekanik dilbilgisi üzerine kurulmuş, yazının niteliği içerikten ziyade şekil açısından ölçülmüş̧ür. "Özerk bir nesne olarak" metinler, öğrenciler tarafından bitirildikten sonraki haliyle değerlendirilmiş ve cümle düzeyinde ortaya konulan performanslar derecelendirilmiştir. Metin için gramer, sözdizimi ve mekanik yeterli görülmüştür (Yi, 2006: 19). Bireyin zihin evreninde var olan ve birtakım süreçler sonucunda metne dönüştürülen kavram, olay, duygu ve düşünceler bu 
anlayışta göz ardı edilmiştir. Aynı şekilde, yazma sürecinde, zihinsel planda ortaya çıkan sorun alanları ile metinleştirme sürecinde ortaya çıkan eş zamanlı ve yinelemeli işlemler dikkate alınmamıştır. Zihinsel süreçleri göz ardı eden bu yaklaşımda bireysel farklılıklar ve yazma kaygısı gibi üretimin niteliğini doğrudan etkileyen faktörler de önemsenmemiştir. Bunlara ilaveten, öğrencinin akademik başarısında olumsuzlayıcı bir ölçme aracı olarak kullanılan yazılı anlatım, önceden belirlenmiş bir konu etrafinda, tek seferlik ve çizgisel bir üretim olarak görülmüştür. Metinleştirme süreçlerini belli şablon ve kurallarla sınırlayan ürün odaklı yazma anlayışı zamanla eleştirilmiş (Ülper, 2008: 37-41) ve 1960'lı yıllardan itibaren süreç odaklı yazma anlayışı yaygınlık kazanmıştır.

Süreç odaklı yazma üretimi ile ilgili öncül araştırmalar, daha çok profesyonel yazarların metinleri oluştururken neler yaptıkları üzerinde yoğunlaşmıştır (Brandi, 2010: 11). Ancak geçen yüzyılın ortalarından itibaren, eğitim bilimleri alanındaki gelişmeler, yazma becerisinin statik düşünce ve yapılardan ziyade, sürece dayalı kimi zihinsel işlemlerle yürütüldüğüne dair düşüncenin filizlenmesini sağlamıştır. $\mathrm{Bu}$ düşüncenin gelişiminde; dinamik kültürün paydaşı ve parçası olan dilin de dinamik bir yapıda olduğunu ve sürekli değiştiğini, dil birimlerinin bağlamından koparılmaması gerektiğini öne süren anlam bilim ve dil bilim alanındaki gelişmelerin etkili olduğu söylenebilir (Mills, 1953: 20).

1970'lerden sonra yazma sürecinin izlenmesine dayanan deneysel çalışmaların arttığı görülmektedir. 1980'li yıllardan itibaren süreç odaklı yazma anlayışı ile ilgili çalışmalar hem nicelik hem de nitelik olarak artmıştır. Yazma becerisinin iyileştirilmesi amacıyla birçok araştırmacı (Badger ve White, 2000; Scardamalia vd., 1984; Dyson, 1988; Perl, 1980; Raimes, 1985) tarafindan deneysel çalışmalar gerçekleştirilmiştir. Bu çalışmalar içinde en dikkate değer olanlardan biri kuşkusuz Flower ve Hayes'e aittir. Flower ve Hayes'in (1980: 10) yazma görevini yürütenlerin, süreç içindeki bilişsel akışını sözlü düşünme protokolleriyle kayda aldığ 1 deneysel çalışmaları, alanda büyük kabul görmüş ve bir yazma modeli olarak geliştirilmiştir. Bilişsel süreç modeli olarak adlandırılan bu modelde, çizgisel yaklaşımın aksine süreçler arasında hem ileriye hem de geriye doğru yinelemeli ilişkiler kurulmuştur. Yazma; görev çevresi, yazarın uzun süreli belleği ve yazma süreci adı verilen üç ana yapı etrafında formüle edilmiştir (Flower ve Hayes, 1981: 370).

Flower ve Hayes'in bilişsel yaklaşımının etkisiyle metin üretiminde süreç eksenli yaklaşımların ortaya çıkmasından sonra, üstbilişin yazma sürecinde hayatî rol oynadığı görüşü yaygınlaşmıştır. Özellikle, öz düzenleme ve karar verme süreçlerinin yazma performansını artıran kritik rolüne dikkat çekilmiş, yazma becerisinde esas yeteneğin öz düzenleme ve kendini yönetme yeteneği olduğu belirtilmiştir (Farahian, 2017: 736). Nitekim konuyla ilgili kavram ve 
yaklaşımlar, ortaya konulan teorik birikimlerle yerli yerine oturunca, yazma eylemi uygulamalı üstbilişsellik olarak tanımlanmaya başlanmıştır (Hacker vd., 2009: 160-164). Bu arada, süreç odaklı birçok deneysel yazma çalışmasında, Flower ve Hayes'in bilişsel süreç modeli ile Vygotsky'nin sosyokültürel gelişim teorisi bütünleştirilmiştir (Vardenburg, 2006: 378). Dil ve düşünce alanındaki başlıca disiplinleri derinden etkileyen Vygotsky kuramı, 1970'li y1llardan itibaren yazma becerisinde de temel başvuru kaynaklarından biri haline gelmiştir.

Sözü edilen bu çalışmalar devam ederken gelişim psikolojisi alanında bellek ve üst bellek gibi kavramlar üzerinde çalışan Flavell'in ortaya koyduğu üstbiliş teorisi birçok öğrenme alanını kısa sürede etkilemiştir (Harten, 2014: 8). Esas itibariyle teorik arka planı eski olmakla birlikte, çocukların bellek yönetme kurallarını öğrenerek bilişsel yeteneklerini geliştirebileceğini düşünen Flavell'in ilk kez 1976'da kullandığı üstbiliş kavramının, bilişle olan ilişkisi, sınırları, ölçümü gibi muğlak alanlar içermesi nedeniyle tartışmalara konu olduğu bilinmektedir (El-Hindi, 1994: 3). Üst bellek kavramı üzerinde yaptı̆̆1 çalışmalardan hareketle üstbilişe ulaşan Flavell, bilişle ilgili temelde iki yetkinlik alanını öngörmüştür. Bunlardan ilki üstbilişsel bilgi, diğeri ise üstbilişsel kontroldür. Bu ikili yapı, onun üstbiliş tanımlamasında da esas alınmıştır. Flavell, bu ikili yapı ekseninde, üstbiliş̧i, kişinin kendi bilişsel süreçleriyle ilgili bilgisi ve bir amaca yönelik bilişsel süreçlerin izlenmesi ve düzenlenmesi olarak tanımlamıştır (aktaran: Braten, 1991: 182). Flavell ile birlikte, üstbilişin zaman içerisinde neredeyse bir psikoloji ekolüne dönüşmesini sağlayan Brown da üstbilişi, kişinin kendi bilişsel süreçlerine yönelik bilgisi ve bilişsel eylemlerine yönelik kontrolü olarak tanımlamış, öğrencilerin kendileri hakkında sahip oldukları bilgiler ile öğrenme bağlamı hakkındaki bilgilerinin üstbiliş bilgisi olduğunu belirtmiştir (aktaran: Velzen, 2016: 17).

İlk üstbilişsel araştırmaların, ezber gibi görevlerde kullanılan çeşitli stratejilere veya kontrol süreçlerine odaklandığı, 1980 sonrasında ise kapsam bakımından, yazma becerisini de içine alacak biçimde giderek genişlediği görülmektedir (Kim, 1991: 9). Bu çalı̧̧malarda, üstbilişsel yazma stratejileri ana hatlarıla planlama, izleme ve değerlendirme gibi kontrol edici yönetsel bileşenler şeklinde tasarlanmıştır.

Dil öğrenme stratejileri üzerinde yapılan araştırmaların çoğunda öğrencilerin üstbilişsel bilgi ve süreçlerle meşgul oldukları raporlanmıştır (Chamot, 2005: 125). Üstbilişsel stratejiler bireyin öğrenme süreçlerini kontrol etmek için kullandıkları araçlardır. Öğrenme süreci hakkında düşünmek, öğrenmeyi planlamak, öğrenme sürecinde anlama veya üretimi izlemek ve dil görevi tamamlandıktan sonra öz değerlendirme yapmak üstbilişsel strateji kullanımıdır (Chamot vd. 1987: 20). Bu stratejilerin temel görevi bilişi düzenlemeye, 
düşünme ve öğrenme süreçlerini kontrol etmeye yöneliktir (Schraw ve Moshman, 1995: 354).

Yazma becerisinin geliştirilmesine yönelik yukarıda değinilen araştırmalara rağmen, erken dönem araştırmalarıyla ortaya konulan teorik yaklaşımların ve pratik uygulamaların istenilen başarının elde edilmesinde yetersiz kaldığını örneğin Amerika'da, istenilen başarının elde edilemediğini ve ulusal ölçekte "yazma sorunu"nun devam ettiğini- kaydeden çalışmalar bulunmaktadır (Scardamalia, 1984: 3). Scardamalia ve Bereiter'e göre yazma becerisinde öğrencilerin genel olarak zorlandığı beş yeterlik alanı bulunmaktadır: “(a) içerik üretmek, (b) kompozisyonlar için organize bir yapı oluşturmak, (c) hedefleri belirlemek ve nitelikli plan yapmak, (d) yazmanın mekanik yönlerini hızll ve verimli bir şekilde oluşturmak, (e) metni gözden geçirmek ve hedefleri yeniden düzenlemek” (aktaran: Pressley ve Harris, 2008: 84).

2000'li yıllara kıyasla tüm dünyada daha düşük profilli tekno-dijital toplum yapısının var olduğu, yazışmanın teknolojik araçlarla gerçekleşmediği ve doğal olarak yazma alışkanlığ 1 ve disiplini üzerinde olumsuz etkisi olduğu düşünülen dijital yaşam tarzının henüz ortaya çıkmadığı zamanlarda bile ulusal düzeyde “yazma sorunu”nun varlığından söz edilmesi önemlidir.

Benzer biçimde, Türkiye'de yazma becerisi konusunda sorunlar olduğunu tespit eden çalışmalar (Ayyıldız ve Bozkurt, 2006; Bağcı, 2007; Göçer, 2010; Özbay ve Zorbaz, 2012; Sallabaş ve Temizkan, 2009; Tağa ve Ünlü, 2013; Tok ve Ünlü, 2014; Ungan, 2007) bulunmaktadır. İlköğretimin ilk yıllarından itibaren çocuğa kazandırılmaya çalışılan yazma becerisi, eğitim ve öğretim süreçleri, hatta yaşam boyu devam eden ve ihtiyaç duyulan bir beceridir. Son yıllarda, yapılandırıcı yaklaşımla hazırlanan öğretim programlarında, elbette daha iyi sonuç elde etmek amaciyla, dil becerilerinin zihinsel, duygusal ve sosyal becerilerle ilişkili olarak geliştirilmesine çaba gösterilmektedir (Güneş, 2011: 123). Ancak eldeki veriler, yazma becerisi alanında sorunların devam ettiğini göstermektedir:

Yazma becerisini de içeren dil öğretimi sürekli geliştirilmesi gereken açık yapılı bir disiplindir. Günümüzün sürekli değişen ve dönüşen toplumsal yapısı ve buna paralel olarak farklılaşan bireysel gereksinimler dil öğretimi konusundaki yerleşik paradigmaların gözden geçirilmesini zorunlu kılmaktadır. Son yıllarda yapılandırıcı yaklaşımla hazırlanan Türkçe Öğretim Programlarında üstbiliş kavramına vurgu yapılmakta, dil becerileri sınıflar düzeyinde tasnif edilen stratejilere dayalı olarak verilmektedir. Üstbilişsel yazma stratejilerine dayalı olarak yürütülen bu çalışma, kaynağını stratejik yaklaşımdan aldığından, yürürlükteki programın içerik ve hedefleriyle uyum sağlamaktadır. 
Yazma becerisinin kazandırılmasında yaşanan sorunların çözümüne katkı sunması beklenen bu araştırmanın problem cümlesi "Üstbilişsel stratejilere dayalı yazma eğitimi, öğrencilerin üstbilişsel yazma farkındalıklarını, yazma becerilerini ve yazma tutumunu nasıl etkilemektedir?” şeklinde belirlenmiştir. $\mathrm{Bu}$ doğrultuda aşağıdaki alt problemlere cevap aranmıştır:

Üstbilişsel yazma stratejileri eğitimi verilen deney grubu öğrencileriyle, üstbilişsel yazma stratejileri eğitimi verilmeyen kontrol grubu öğrencilerinin;

1. Üstbilişsel yazma stratejileri farkındalıkları arasında anlamlı bir farklılık var midır?

2. Yazma tutumları arasında anlamlı bir farklılık var mıdır?

3. Yazma becerisindeki başarı durumlarında anlamlı bir farklılık var mıdır?

4. Deney grubu öğrencilerinin üstbiliş stratejileri kullanılarak yapılan yazma çalışmalarına ilişkin görüşleri nelerdir?

\section{YÖNTEM}

\section{Araştırmanın Modeli}

Çalışmada, hem nitel hem de nicel araştırma yöntemlerinin birlikte yer aldığı karma yöntemlerden açıklayıcı sıralı desen kullanılmıştır. $\mathrm{Bu}$ desen, nicel eğilimin nitel eğilime göre baskın olduğu, nicel verilerin nitel verilerle desteklendiği bir araştırma desenidir ve iki aşamadan oluşmaktadır. Nicel verilerin toplanması ve analiz edilmesi ilk aşamada, nicel verileri tamamlayıcı ve açıklayıcı nitelikte olan nitel veriler ise ikinci aşamada toplanır. Böylece ikinci aşama ilk aşamanın üzerine bina edilir (Özden ve Durdu, 2016: 80). Bu desende nitel verilerin kullanılmasındaki aslı amaç daha güçlü sonuçlara ulaşmak (Creswell, 2007: 33), nicel verileri daha ayrıntılı açıklamaktır (Creswell, 2017: 225). Araştırmanın nicel aşamasında, gerçek deneysel desenlerden biri olan ön test ve son test kontrol gruplu seçkisiz desen kullanılmıştır. Araştırma kapsamında, seçkisiz atama yöntemiyle biri deney diğeri kontrol olmak üzere iki grup oluşturulmuştur.

Araştırmanın nitel boyutunda, öğrenci görüşlerine başvurulmuştur. Görüşleri alınmak üzere öğrenci seçimi yapılırken, amaçlı örnekleme yöntemlerinden ölçüt örneklemesi kullanılmıştır. "Bu örnekleme yöntemindeki temel anlayış önceden belirlenmiş bir dizi ölçütü karşllayan bütün durumların çalışılmasıdır." (Yıldırım ve Şimşek, 2018: 122). Bu kapsamda seçilen öğrencilerin son test puanları temel ölçüt olarak belirlenmiş; en yüksek, orta ve en düşük puanlı 21 öğrenciyle görüşme yapılmıştır. Yarı yapılandırılmış 
görüşme formuyla elde edilen görüşler betimsel analiz yöntemiyle incelenmiştir. $\mathrm{Bu}$ çalışmadaki bütün veri toplama araçları için İnönü Üniversitesi Bilimsel Araştırma ve Yayın Etiği Kurulu-Sosyal ve Beşeri Bilimler Araştırma ve Yayın Etik Kurulundan 06.07.2020 tarihli ve Karar sayısı: 5 olan Etik Kurul izni alınmıştır.

\section{Çalışma Grubu}

Araştırma, Kahramanmaraş'ın Onikişubat ilçesindeki AKEDAŞ Ortaokulunda $7 / \mathrm{C}$ ve 7/D sınıfı öğrencileriyle uzaktan eğitimle yürütülmüştür. Seçilen ortaokulun eğitsel açıdan il merkezinin genel ortalamasına yakın olması gözetilmiştir. Araştırmanın yürütüldüğü okulda $C$ ve $D$ şubelerinin dersine giren öğretmenin çalışmayı gönüllü olarak yürütmeyi kabul etmesi sonucunda, kura yöntemiyle D şubesi deney, C şubesi kontrol grubu olarak seçilmiştir. Ders öğretmeninin verdiği bilgiler doğrultusunda, her iki sınıfta derslere genel olarak devam eden öğrencilerden 30'ar kişilik gruplar oluşturulmuştur. Daha sonra iki grup arasında homojenlik olup olmadığını belirlemek için veri toplama araçlarılya ön testler yapılmış, grupların istatistiksel olarak eşit düzeyde oldukları belirlenmiştir. Çalışma grubunu oluşturan öğrencilerden elde edilen ön test verilerinin normallik sınaması Tablo 1'de verilmiştir:

Tablo 1. Deney ve Kontrol Gruplarında Veri Toplama Araçlarından Elde Edilen Ön Test Puanlarına İlişkin Shapiro-Wilk Testi Sonuçları

\begin{tabular}{lllcccc}
\hline & Testler & Gruplar & $\mathbf{N}$ & $\overline{\mathbf{X}}$ & Ortanca & Shapiro-Wilk (p) \\
\hline \multirow{2}{*}{ ÜYSÖ } & \multirow{2}{*}{ On Test } & Deney & 30 & 4.053 & 4.100 & .077 \\
& & Kontrol & 30 & 4.120 & 4.150 & .084 \\
\hline \multirow{2}{*}{ YYTÖ } & \multirow{2}{*}{ Ön Test } & Deney & 30 & 3.717 & 3.700 & .596 \\
& & Kontrol & 30 & 3.903 & 4.000 & .123 \\
\hline \multirow{2}{*}{ ÖYBM } & \multirow{2}{*}{ Ön Test } & Deney & 30 & 66.783 & 68.150 & .415 \\
& & Kontrol & 30 & 65.513 & 66.700 & .117 \\
\hline
\end{tabular}

ÜYSÖ: Üstbilişsel Yazma Stratejileri Ölçeği,

YYTÖ: Yazmaya Yönelik Tutum Ölçeği,

ÖYBM: Öğrencilerin Yazdığı Bilgilendirici Metinler

Tablo 1'de; sırasıyla, ÜYSÖ, YYTÖ ve ÖYBM'ye ilişkin öğrenci sayıları, ortalamalar, ortancalar ve normallik sonuçları verilmiştir. Buna göre, deney ve kontrol gruplarındaki öğrencilerin; ÜYSÖ, YYTÖ ve ÖYBM ön test verileri normal dağ 1 lım göstermiştir ( $\left.\mathrm{p}^{>} .05\right)$.

Deney ve kontrol gruplarından elde edilen verilerin homojenliği için yapılan Levene testi sonuçları incelendiğinde; ÖYBM ön test puanları $(\mathrm{F}=.821$, $\mathrm{p}>.05, \mathrm{p}=.369)$ ile ÜYSÖ $(\mathrm{F}=.829, \mathrm{p}>.05, \mathrm{p}=.366)$ ve YYTÖ $(\mathrm{F}=.021, \mathrm{p}>$ $.05, \mathrm{p}=.885)$ puanlarının homojen olduğu tespit edilmiştir. 
T.Erol-H.Kavruk Üstbilissel Yazma Stratejileri Eğitiminin Yazma...

Uygulama öncesinde, bağımsız gruplar t-testi ile öğrencilerin ön test puanları/giriş davranışları arasında istatistiksel olarak anlamlı fark olup olmadığa incelenmiştir. Deney ve kontrol grubundaki öğrencilerin tüm veri toplama araçlarından aldıkları ön test puanları arasında istatistiksel olarak anlamlı bir fark olup olmadığını belirlemek için yapılan bağımsız gruplar t-testi Tablo 2'de sunulmuştur:

Tablo 2. Deney ve Kontrol Gruplarında Veri Toplama Araçlarından Elde Edilen Ön Test Puanlarının Karşılaştırılmasına Yönelik Bağımsız Gruplar TTesti Sonuçları

\begin{tabular}{|c|c|c|c|c|c|c|c|}
\hline & Gruplar & $\mathbf{N}$ & $\overline{\mathbf{X}}$ & SS & Sd & $\mathbf{t}$ & $\mathbf{p}$ \\
\hline \multirow{2}{*}{ ÜYSÖ } & Deney Grubu & 30 & 4.053 & 3277 & \multirow{2}{*}{58} & \multirow{2}{*}{.698} & \multirow{2}{*}{488} \\
\hline & Kontrol Grubu & 30 & 4.120 & .4080 & & & \\
\hline \multirow{2}{*}{ YYTÖ } & Deney Grubu & 30 & 3.717 & .4276 & \multirow{2}{*}{58} & \multirow{2}{*}{1.749} & \multirow{2}{*}{.086} \\
\hline & Kontrol Grubu & 30 & 3.903 & .3987 & & & \\
\hline \multirow{2}{*}{ ÖYBM } & Deney Grubu & 30 & 66.783 & 11.93 & \multirow{2}{*}{58} & \multirow{2}{*}{.369} & \multirow{2}{*}{.714} \\
\hline & Kontrol Grubu & 30 & 65.513 & 14.60 & & & \\
\hline
\end{tabular}

Tablo 2'de, deney ve kontrol gruplarının üç veri toplama aracında, birbirine yakın ortalamalar elde ettiği görülmektedir. Grupların ortalama puanlarının farklılık taşıyıp taşımadığını belirlemek için yapılan bağımsız gruplar t-testi sonucuna göre, her üç ölçme aracından elde edilen ortalamalar arasında anlamlı düzeyde bir farklılık bulunmamaktadır. Bu durumda, deneysel işlem öncesinde iki grubun üstbilişsel yazma stratejileri farkındalık düzeyi, yazmaya yönelik tutum ile yazma becerisi başarı düzeyi bakımından denklik taşıdı̆̆ söylenebilir.

\section{Veri Toplama Araçları}

Veriler, araştırmacı tarafından geliştirilen veri toplama araçlarıyla elde edilmiştir. Araştırma kapsamında elde edilen veriler nicel ve nitel olmak üzere iki çeşittir. Nicel veriler; üstbilişsel yazma stratejileri ölçeği, yazmaya yönelik tutum ölçeği, öğrencilerin yazdığı bilgilendirici metinler ve bu metinlerin puanlanması için geliştirilen üstbilişsel yazma stratejilerine yönelik dereceli puanlama anahtarı (DPA) ile toplanmıştır. Nitel veriler ise yarı yapılandırılmış görüşme formuyla elde edilmiştir.

\section{Uygulama Süreci}

Tablo 3. Deney ve Kontrol Grubu Uygulama Planı

Çalışma grubuna ilk haftanın farklı günlerinde üstbilişsel yazma 1. Hafta stratejileri ölçeği ile yazma becerisi tutum ölçeğinin uygulanmasi. Çalışma grubuna ön testin uygulanması.

\begin{tabular}{lll}
\hline Deney Grubu & & \\
\hline 2. Hafta & Planlama Stratejisi & Çalışmalar hakkında öğrencilerin
\end{tabular}




\begin{tabular}{|c|c|c|}
\hline & $\begin{array}{l}\text { Alt strateji: } \\
\text { Ön Örgütleyiciler }\end{array}$ & $\begin{array}{l}\text { bilgilendirilmesi, etkinliklerin } \\
\text { uygulama ilkelerinin sunulması, ön } \\
\text { örgütleme ile ilgili eğitimin } \\
\text { verilmesi. }\end{array}$ \\
\hline 3. Hafta & $\begin{array}{l}\text { Alt strateji: } \\
\text { İşlevsel planlama }\end{array}$ & $\begin{array}{l}\text { İşlevsel planlama stratejisi ile ilgili } \\
\text { eğitimin verilmesi. }\end{array}$ \\
\hline 4. Hafta & $\begin{array}{l}\text { Alt strateji: } \\
\text { Yönlendirilmiş dikkat } \\
\text { Isşlevsel planlama }\end{array}$ & $\begin{array}{l}\text { Yönlendirilmiş dikkat ve işlevsel } \\
\text { planlama stratejileri ile ilgili } \\
\text { eğitimin verilmesi. }\end{array}$ \\
\hline 5. Hafta & $\begin{array}{l}\text { Kendini İzleme Stratejisi } \\
\text { Alt stratejiler: } \\
\text { Kavramayı izleme } \\
\text { Üretimi izleme } \\
\text { Stili İzleme }\end{array}$ & $\begin{array}{l}\text { Kavramayı izleme, üretimi izleme } \\
\text { ve stili izleme stratejilerini kullanma } \\
\text { ile ilgili eğitimin verilmesi. }\end{array}$ \\
\hline 6. Hafta & $\begin{array}{l}\text { Alt stratejiler: } \\
\text { Stratejiyi izleme } \\
\text { Planı izleme } \\
\text { Çift kontrollü izleme }\end{array}$ & $\begin{array}{l}\text { Stratejiyi izleme, planı izleme ve } \\
\text { çift kontrollü izleme stratejilerini } \\
\text { kullanma ile ilgili eğitimin } \\
\text { verilmesi. }\end{array}$ \\
\hline 7. Hafta & $\begin{array}{l}\text { Öz Değerlendirme Stratejisi } \\
\text { Alt stratejiler: } \\
\text { Üretimi değerlendirme } \\
\text { Performansı değerlendirme }\end{array}$ & $\begin{array}{l}\text { Üretimi değerlendirme ve } \\
\text { performans1 değerlendirme } \\
\text { stratejileri ile ilgili eğitimin } \\
\text { verilmesi. }\end{array}$ \\
\hline 8. Hafta & $\begin{array}{l}\text { Alt stratejiler: } \\
\text { Yeteneği değerlendirme } \\
\text { Stratejiyi değerlendirme }\end{array}$ & $\begin{array}{l}\text { Yeteneği değerlendirme ve stratejiyi } \\
\text { değerlendirme stratejileri ile ilgili } \\
\text { eğitimin verilmesi. }\end{array}$ \\
\hline 9. Hafta & \multicolumn{2}{|c|}{$\begin{array}{l}\text { Üstbilişsel yazma stratejileri kullanarak metin üretme (uygulama) } \\
\text { çalışması. } \\
\text { Strateji eğitimi sürecinin değerlendirilmesi ve strateji transferine } \\
\text { yönelik etkinliklerin yapılması. }\end{array}$} \\
\hline 10. Hafta & \multicolumn{2}{|c|}{$\begin{array}{l}\text { Çalışma grubuna son haftanın farklı günlerinde son test, üstbilişsel } \\
\text { yazma stratejileri farkındalık ölçeği ile yazma becerisine yönelik } \\
\text { tutum ölçeği tekrar uygulanması. } \\
\text { Öğrencilere yarı yapılandırılmış görüșme formunun uygulanması. }\end{array}$} \\
\hline
\end{tabular}

Etik kurul izni alındıktan sonra, araştırmanın uygulama boyutu 07.09.202013.11.2020 arasında gerçekleşmiştir. Bütün uygulama çalışmaları ders öğretmeni tarafından yürütülmüştür. Deneysel işlem öncesinde, üstbilişsel yazma stratejilerine yönelik olarak araştırmacı tarafından hazırlanan etkinlik kitapçıkları ders öğretmeni aracılığıyla deney grubundaki öğrencilere dağıtılmıştır. Bu kitapçıklardaki tüm içerikler literatüre dayalı olarak araştırmacı tarafından üretilmiştir. Etkinlikler, şekiller, sayfa düzeni gibi unsurlar araştırmacı tarafından tasarlanmıştır. Üstbilişsel yazma stratejilerine dayalı olarak hazırlanan etkinlik kitapçı ̆̆ 1 için MEB'e bağlı ortaokullarda Türkçe öğretmenliği yapan ve Türkçe eğitimi alanında doktora eğitimini sürdüren dört öğretmenden uzman görüşü alınmıştır. Etkinliklerin seviyeye uygunluğu, 
hedeflenen kazanımları karşılama düzeyi, uygulanabilirliği, verilme sırası, özerk veya öz düzenleyici öğrenmeyi teşvik ediciliği, sayıca yeterliği, üstbilişsel yazma stratejileri becerisini geliştirmeye katkısı ile öğrencilerin sürece aktif biçimde katılımını yordayıp yordamadığı uzmanlar tarafindan değerlendirilmiştir. Uzman görüşleri dikkate alınarak kitapçıklar üzerinde gerekli değişiklikler yapılmıştır. Deney grubundaki etkinlikler, hazırlanan etkinlik kitapçığı dâhilinde yürütülmüştür. Kontrol grubunda ise MEB'in mevcut öğretim programı doğrultusunda eğitim yapılmıştır. Uygulamaların ilk ve son haftası ön testler ve son testlere ayrılmıştır. Aradaki 8 hafta boyunca ikişer ders saatinde uygulama çalışmaları gerçekleştirilmiştir. Üstbilişsel yazma stratejilerine yönelik uygulamalar aşağıdaki sırada gerçekleştirilmiştir:

\section{Verilerin Analizi}

Araştırma kapsamında elde edilen verilerin analizi için nicel ve nitel veri analiz yöntemleri kullanılmıştır. Araştırma denenceleri .05 anlamlılık düzeyinde test edilmiştir. Verilerin normallik gösterip göstermediği Shapiro-Wilk testi ile test edilmiş, betimleme tablosundaki çarpıklık, basıklık, ortalama ve ortanca değerleri dikkate alınmıştır. Homojenlik için Levene testi kullanılmıştır. Levene testi, eşvaryanslıllğı esas alan, varyanslar arasında homojenliği belirleyen bir testtir. Testin sig. (p) değerinin 0.05 'ten büyük olması durumunda gruplar arasında fark olmadığı, varyansların eşit olduğu sonucuna varılmıştır (Çokluk vd., 2018: 20). Deney ve kontrol gruplarının son testlerinden elde edilen puanların istatistiksel olarak anlamlı fark yaratıp yaratmadığını belirlemek için ön test ile son test arasındaki puan farkı incelenmiştir (Büyüköztürk, 2017: 67).”

Testlerin normallik varsayımını karşılaması durumunda; gruplar arası karşılaştırmalarda ön test ve son test puanları arasındaki farkın anlamlılı̆̆ını belirlemek için bağımsız gruplar $t$ testi, grupların kendi içindeki ön test ve son test puanları arasındaki farkın anlamlılığını belirlemek için bağımlı gruplar ttesti kullanılmıştır. Testlerin normallik varsayımını karşılamadığı durumlarda; gruplar arasındaki son test puan farkının anlamlılığını belirlemek için MannWhitney U testi, grup içi karşılaştırmalarda ön test ve son test puanları arasındaki farkın anlamlı olup olmadığına yönelik ölçümlerde Wilcoxon işaretli sıralar testi yapılmıştır. Öğrenciler tarafından üretilen metinlerin değerlendirmesini yapan puanlayıcıların kendi aralarındaki uyumunu ölçmek için Kendall's W testi kullanılmıştır.

Deney grubundaki öğrencilerin üstbilişsel yazma stratejilerini kullanmaya yönelik görüsşlerini içeren nitel veriler, yarı yapılandırılmış görüşme tekniğiyle elde edilmiştir. Yarı yapılandırılmış görüşme formlarıyla elde edilen öğrenci görüşleri betimsel analiz yöntemiyle incelenmiştir. Elde edilen kategoriler, güvenirliği sağlamak amacıyla, Türkçe eğitimi alanında çalışan iki 
akademisyenin görüşüne sunulmuştur. Uzlaşım sağlanamayan hususlar, araştırmacı ve iki uzman tarafindan yeniden değerlendirilmiş ve son aşamada sadece görüş birliği sağlanan kategoriler dikkate alınmıştır. Tasnif edilen veriler daha sonra tablo hâline getirilmiş ve yorumlanmıştır.

\section{BULGULAR VE YORUM}

Çalışmanın bulguları dört temel problem cümlesi altında incelenmiştir.

\section{Öğrencilerin Üstbilişsel Yazma Stratejileri Farkındalıklarına İlişkin Bulgu ve Yorumlar}

Öğrencilerin ÜYSÖ farkındalık düzeyini tespit etmek amacıyla öncelikle grup içi karşılaştırmalar yapılmış, öğrencilerin ön test ile son test puanları arasında fark olup olmadığ 1 belirlenmiştir. Karşılaştırma öncesinde, her bir grubun (grup içi) ÜYSÖ’ye ait erişi (ön test ile son test puanları arasındaki fark) puanları esas alınarak normallik testi yapılmıştır. Deney ve kontrol gruplarındaki erişi puanlarının Shapiro-Wilk testi sonuçları Tablo 4'te verilmiştir:

Tablo 4. Deney ve Kontrol Gruplarının ÜYSÖ’den Elde Ettiği Erişi Puanlarına İlişkin Shapiro-Wilk Testi Sonuçları

\begin{tabular}{llcccc}
\hline Gruplar & Veri Top. Aracı & $\mathbf{N}$ & $\overline{\mathbf{X}}$ & Ortanca & Shapiro-Wilk (p) \\
\hline Deney & ÜYSÖ & 30 & .440 & .400 & .130 \\
\hline Kontrol & ÜYSÖ & 30 & .047 & .050 & .579 \\
\hline
\end{tabular}

Tablo 4'teki Shapiro-Wilk testinde, grupların kendi içlerindeki ön test ile son test puan farklarına dayanan erişi puanlarının normal dağılım gösterdiği anlaşılmaktadır $(\mathrm{p}>.05)$. Bu nedenle deney ve kontrol grubunun grup içi karşılaştırmaları bağımlı gruplar $\mathrm{t}$ testi ile yapılmıştır.

Tablo 5. Deney ve Kontrol Grubunun ÜYSÖ Ön Test ve Son Test Puanlarının Karşılaştırılmasına Yönelik Bağımlı Gruplar T-Testi Sonuçları

\begin{tabular}{|c|c|c|c|c|c|c|c|}
\hline Gruplar & Testler & $\mathbf{N}$ & $\overline{\mathbf{X}}$ & SS & Sd & $t$ & p \\
\hline \multirow{2}{*}{ Deney } & Ön test & 30 & 4.053 & .3277 & \multirow{2}{*}{29} & \multirow{2}{*}{7.739} & \multirow{2}{*}{$.000^{*}$} \\
\hline & Son test & 30 & 4.493 & .1760 & & & \\
\hline \multirow{2}{*}{ Kontrol } & Ön test & 30 & 4.120 & .4080 & \multirow[t]{2}{*}{29} & \multirow[t]{2}{*}{579} & \multirow[t]{2}{*}{.567} \\
\hline & Son test & 30 & 4.167 & .5616 & & & \\
\hline
\end{tabular}

$* \mathrm{p}<.05$

Tablo 5'teki bağımlı gruplar t-testi sonucuna göre, üstbilişsel yazma stratejileri eğitimi alan deney grubundaki öğrencilerin ölçeğe yönelik ön test ile 
$\underline{\text { T.Erol-H.Kavruk Üstbilissel Yazma Stratejileri Eğitiminin Yazma... }}$

son test toplam puanları arasında istatistiksel olarak anlamlı bir fark oluşmuştur $\left[\mathrm{t}_{(29)}=7.739, \mathrm{p}<\right.$.05]. Buna göre, üstbilişsel yazma stratejileri eğitiminin deney grubu üzerinde olumlu etki yaptığı söylenebilir. Deneysel işlem süresince herhangi bir yapay müdahaleye maruz kalmayan kontrol grubunda ön test ve son test verileri arasında istatistiksel olarak anlamlı bir fark bulunmadığ 1 anlaşılmaktadır $\left[\mathrm{t}_{(29)}=.579, \mathrm{p}>.05\right]$. Bu sonuca göre, çalışmanın yürütüldüğ̈̈ süreç içerisinde kontrol grubu öğrencilerinin üstbilişsel yazma stratejileri farkındalık düzeylerinde anlamlı bir farklılığın meydana gelmediği söylenebilir.

Deneysel işlemin gruplar arasında nasıl bir farklılık oluşturduğunu belirlemek için deney ve kontrol grubu öğrencilerinin ÜYSÖ farkındalık düzeylerine yönelik son test bulguları da karşılaştırılmıştır. Grupların son test verilerine ilişkin normallik testi Tablo 6' da yer almaktadır.

Tablo 6. Deney ve Kontrol Gruplarının ÜYSÖ'den Elde Ettiği Son Test Puanlarına İlişkin Shapiro-Wilk Testi Sonuçları

\begin{tabular}{llcccc}
\hline & Gruplar & $\mathbf{N}$ & $\overline{\mathbf{X}}$ & Ortanca & Shapiro-Wilk (p) \\
\hline \multirow{2}{*}{ ÜYSÖ } & Deney & 30 & 4.493 & 4.500 & .139 \\
& Kontrol & 30 & 4.117 & 4.300 & $.028^{*}$ \\
\hline
\end{tabular}

$* \mathrm{p}<.05$

Tablo 6'daki Shapiro-Wilk testi sonuçlarına göre, kontrol grubunun ÜYSÖ son test puanları normal dağılım göstermemiştir $(\mathrm{p}<.05)$. Deney grubunun ÜYSÖ son test puanları ise normal dağılmıştır ( $>>05$ ). Gruplardan en az birinin verileri normal dağılım göstermediğinden, gruplar arası karşılaştırma yapılırken parametrik olmayan testlerden Mann-Whitney U testi kullanılmıştır. Deney ve kontrol grubu öğrencilerinin ÜYSÖ’ye ilişkin son test puanları Tablo 7'de karşılaştırılmaktadır:

Tablo 7. Deney ve Kontrol Gruplarının ÜYSÖ Son Test Puanlarının Karşılaştırılmasına Yönelik Mann-Whitney U Testi Sonuçları

\begin{tabular}{lccccc}
\hline Gruplar & N & Sira Ort. & Sira Top. & U & p \\
\cline { 1 - 4 } Deney Grubu & 30 & 34.98 & 1049,50 & \multirow{2}{*}{315.500} & \multirow{2}{*}{$.046^{*}$} \\
\cline { 1 - 5 } Kontrol Grubu & 30 & 26.02 & 780,50 & & \\
\hline
\end{tabular}

$* \mathrm{p}<.05$

Tablo 7'de, son test puanlarının deney ve kontrol gruplarına göre farklılaşıp farklılaşmadığını ortaya koymak amaciyla yapılan Mann-Whitney U testi sonucuna göre deney grubu lehine istatistiksel olarak anlamlı farklılik gözlenmiştir $(\mathrm{U}=315.5 ; \mathrm{p}<$.05). Bu sonuca göre, çalışmanın bağımsız değişkeni olan üstbilişsel yazma stratejileri eğitimi deney grubu lehine olumlu yönde etki yaratmıştır.

\section{Öğrencilerin Yazma Tutumuna Yönelik Bulgu ve Yorumlar}


Deney ve kontrol grubunun YYTÖ ön test ile son test puanları arasında fark olup olmadığını belirlemek için erişi puanları esas alınarak normallik testi yapılmıştır. Deney ve kontrol gruplarındaki erişi puanlarının Shapiro-Wilk testi sonuçları Tablo 8'de verilmiştir:

Tablo 8. Deney ve Kontrol Gruplarının YYTÖ’den Elde Ettiği Erişi Puanlarına İlişkin Shapiro-Wilk Testi Sonuçları

\begin{tabular}{llllll}
\hline Gruplar & Veri Top. Aracı & $\mathrm{N}$ & $\overline{\mathbf{X}}$ & Ortanca & Shapiro-Wilk (p) \\
\hline Deney & YYTÖ & 30 & .363 & .400 & $.033^{*}$ \\
\hline Kontrol & YYTÖ & 30 & .173 & .300 & .550 \\
\hline$* \mathrm{p}<.05$ & & & & &
\end{tabular}

Tablo 8'deki Shapiro-Wilk testine göre, deney grubunun verileri normallik varsayımını karşılamamaktadır $(\mathrm{p}<.05)$. Kontrol grubunda ise veriler normal dağılmıştır ( $\mathrm{p}>.05)$. Bu nedenle deney grubunun grup içi karşılaştırması yapılırken parametrik olmayan Wilcoxon işaretli sıralar testi (Tablo 9) kullanılmıştır. Kontrol grubundaki veriler normal dağılım gösterdiğinden, karşılaştırmalarda parametrik testlerden biri olan bağımlı gruplar t testi (Tablo 10) kullanılmıştır.

Tablo 9. Deney Grubunun YYTÖ Ön Test ve Son Test Puanlarının Karşılaştırılmasına Yönelik Wilcoxon İşaretli Sıralar Testi Sonuçları

\begin{tabular}{lccccc}
\hline Ön Test-Son Test & $\mathbf{N}$ & Sıra Ort. & Sira Top. & $\mathbf{Z}$ & p \\
\hline Negatif Sıralar & $6^{\mathrm{a}}$ & 12.50 & 75.00 & 2.919 & $.004^{*}$ \\
Pozitif Sıralar & $22^{\mathrm{b}}$ & 15.05 & 331.00 & & \\
Eşit Sıralar & $2^{\mathrm{c}}$ & & & & \\
Toplam & 30 & & & & \\
\hline$* \mathrm{p}<.05$ & a. son test $<$ ön test & b. son test $>$ ön test & c. & son \\
test $=$ ön test & & & & &
\end{tabular}

Tablo 9'da üstbilişsel yazma stratejileri eğitimi alan deney grubundaki öğrencilerin yazma tutum ölçeği ön test ile son test puanları karşılaştırılmıştır. Buna göre deney grubunun ön test ile son testi arasındaki fark istatistiksel olarak anlamlı bulunmuştur. $\mathrm{Bu}$ farklılık son test lehine gerçekleşmiştir. Şu halde, deney grubunda, deneysel işlemin etkisiyle yazmaya yönelik olumlu tutum geliştiği söylenebilir [ $\mathrm{Z}=2.919 ; \mathrm{p}<$.05].

Tablo 10. Kontrol Grubunun YYTÖ Ön Test ve Son Test Puanlarının Karşılaştırılmasına Yönelik Bağımlı Gruplar T-Testi Sonuçları

\begin{tabular}{|c|c|c|c|c|c|c|}
\hline Testler & $\mathbf{N}$ & $\overline{\mathbf{X}}$ & SS & Sd & t & p \\
\hline Ön test & 30 & 3.903 & 3987 & \multirow{2}{*}{29} & \multirow{2}{*}{1.872} & \multirow{2}{*}{.071} \\
\hline Son test & 30 & 3.730 & .6773 & & & \\
\hline
\end{tabular}


$\underline{\text { T.Erol-H.Kavruk Üstbilissel Yazma Stratejileri Eğitiminin Yazma... }}$

Tablo 10 incelendiğinde, üstbilişsel yazma stratejileri eğitimi verilmeyen kontrol grubundaki öğrencilerin, yazma tutum ölçeği ön test ile son test puanları arasında istatistiksel olarak anlamlı bir fark oluşmadığı anlaşılmaktadır $\left[\mathrm{t}_{(29)}=\right.$ 1.872, $\mathrm{p}>.05]$.

Deney ve kontrol grubunun YYTÖ son test puanları için gruplar arası karşılaştırmalar da yapılmıştır. Karşılaştırma öncesinde, deney ve kontrol gruplarının son test puanları arasında normal dağılım olup olmadı̆̆ incelenmiştir. YYTÖ son test puanlarına yönelik Shapiro-Wilk testi sonuçları Tablo 11'de verilmiştir:

Tablo 11. Deney ve Kontrol Gruplarında YYTÖ’den Elde Edilen Son Test Puanlarına İlişkin Shapiro-Wilk Testi Sonuçları

\begin{tabular}{llcccc}
\hline & Gruplar & $\mathbf{N}$ & $\overline{\mathbf{X}}$ & Ortanca & Shapiro-Wilk (p) \\
\hline \multirow{2}{*}{ YYTÖ } & Deney & 30 & 4.070 & 4.100 & .271 \\
& Kontrol & 30 & 3.730 & 3.750 & .319 \\
\hline
\end{tabular}

Tablo 11'deki Shapiro-Wilk testi sonuçlarına göre, grupların verileri normal dağılmıştır ( $\mathrm{p}>.05)$. Bu sonuçlardan hareketle, deney ve kontrol gruplarının puanları bağımsız gruplar $t$ testi ile karşılaştırılmıştır. Deney ve kontrol grubu öğrencilerinin YYTÖ son test puanları Tablo 12'de karşılaştırılmaktadır:

Tablo 12. Deney ve Kontrol Gruplarının YYTÖ Son Test Puanlarının Karşılaştırılmasına İlişkin Bağımsız Gruplar T-Testi Sonuçları

\begin{tabular}{|c|c|c|c|c|c|c|}
\hline Gruplar & $\mathbf{N}$ & $\overline{\mathbf{X}}$ & SS & Sd & t & $\mathbf{p}$ \\
\hline Deney & 30 & 4.070 & .4580 & \multirow{2}{*}{50.935} & \multirow{2}{*}{2.278} & \multirow{2}{*}{$.027^{*}$} \\
\hline Kontrol & 30 & 3.730 & .6773 & & & \\
\hline
\end{tabular}

$* \mathrm{p}<.05$

Tablo 12'deki bağımsız gruplar $\mathrm{t}$ testine göre, iki gruba ait son test puanları arasında meydana gelen farklılık istatistiksel olarak anlamlı bulunmuştur $\left[\mathrm{t}_{(50,935)}\right.$ $=2.278, \mathrm{p}<.05]$. Bu durumda, üstbilişsel yazma stratejileri eğitiminin deney grubundaki öğrencilerin yazmaya yönelik tutumunu olumlu yönde etkilediği söylenebilir.

\section{Öğrencilerin Yazma Becerisindeki Başarı Durumlarına Yönelik Bulgu ve Yorumlar}

Deney ve kontrol gruplarında ÖYBM, araştırmacı tarafından geliştirilen üstbilişsel yazma stratejilerine yönelik dereceli puanlama anahtarı kullanılarak değerlendirilmiştir. Üretilen metinler üç puanlayıcı tarafından bağımsız biçimde puanlanmıştır. Puanlayıcılar arasındaki uyumu ve puanlamanın geçerlik ve güvenirliğini test eden Kendall's W testi sonuçları aşağıda sunulmaktadır: 
Tablo 13. Deney ve Kontrol Gruplarında ÖYBM’yi Değerlendiren Puanlayıcılara Yönelik Kendall's W Testi Sonuçları

\begin{tabular}{cllllc}
\hline & Gruplar & Testler & N & Sd & Kendall's W $^{\text {a }}$ \\
\hline \multirow{4}{*}{ ÖYBM } & \multirow{2}{*}{ Deney } & Ön Test & 3 & 29 & .884 \\
\cline { 2 - 5 } & \multirow{2}{*}{ Kontrol } & Son Test & 3 & 29 & .809 \\
\cline { 3 - 6 } & & Ön Test & 3 & 29 & .890 \\
& & Son Test & 3 & 29 & .886 \\
\hline
\end{tabular}

Tablo 13'te deney ve kontrol grupları tarafindan üretilmiş metinlere üç puanlayıcı tarafından verilen puanların uyumu ile geçerlik ve güvenirliği Kendall's W testi ile analiz edilmiştir. Elde edilen sonuca göre puanlayıcılar arasındaki uyum .809 ile .890 arasında değişmektedir. Başka bir ifadeyle puanlayıcılar arasında yaklaşık \% 81 ile \% 89 arasında uyum gerçekleşmiştir. $\mathrm{Bu}$ sonuç, üstbilişsel yazma stratejilerine yönelik dereceli puanlama anahtarının geçerli ve güvenilir bir ölçüm aracı olduğunu göstermektedir.

ÖYBM'ye ilişskin karşılaştırmalar yapılmadan önce, her bir grubun ÖYBM ilk ölçüm ile son ölçüm puanları arasındaki farkı esas alan erişi puanlarına göre normallik sınaması yapılmıştır. Tablo 14'te bu bulgulara yer verilmiştir:

Tablo 14. Deney ve Kontrol Gruplarında ÖYBM'den Elde Edilen Erişi Puanlarına İlişkin Shapiro-Wilk Testi Sonuçları

\begin{tabular}{lllccc}
\hline & Gruplar & $\mathbf{N}$ & $\overline{\mathbf{X}}$ & Ortanca & Shapiro-Wilk (p) \\
\hline \multirow{2}{*}{ ÖYBM } & Deney & 30 & 5.300 & 3.350 & .714 \\
& Kontrol & 30 & .530 & -3.150 & .254 \\
\hline
\end{tabular}

Tablo 14'teki Shapiro-Wilk testinde, grupların kendi içindeki ilk ve son puan farklarına dayanan erişi puanları normal dağılım göstermiştir ( $\mathrm{p}>.05) . \mathrm{Bu}$ nedenle çalışma grubunun grup içi karşılaştırmaları bağımlı gruplar $t$ testi ile yapılmıştır. Karşılaştırmalar Tablo 15'te sunulmuştur:

Tablo 15. Deney ve Kontrol Grubunda ÖYBM'ye İlişkin İlk ve Son Ölçüm Puanlarının Karşılaştırılmasına Yönelik Bağımlı Gruplar T-Testi Sonuçları

\begin{tabular}{|c|c|c|c|c|c|c|c|}
\hline Gruplar & ÖYBM & $\mathbf{N}$ & $\overline{\bar{X}}$ & SS & Sd & $\mathbf{t}$ & $\mathbf{p}$ \\
\hline \multirow{2}{*}{ Deney } & İlk Ölçüm & 30 & 66.783 & 11.9305 & \multirow{2}{*}{29} & \multirow{2}{*}{3.306} & \multirow{2}{*}{$.003^{*}$} \\
\hline & Son Ölçüm & 30 & 72.083 & 8.2393 & & & \\
\hline \multirow{2}{*}{ Kontrol } & İlk Ölçüm & 30 & 65.513 & 14.6022 & \multirow[t]{2}{*}{29} & \multirow[t]{2}{*}{.218} & \multirow[t]{2}{*}{.829} \\
\hline & Son Ölçüm & 30 & 66.043 & 14.2588 & & & \\
\hline
\end{tabular}

$* \mathrm{p}<.05$

Tablo 15'teki sonuca göre, deney grubunda son ölçüm lehine istatistiksel olarak anlamlı bir fark oluşmuştur $\left[\mathrm{t}_{(29)}=3.306, \mathrm{p}<.05\right]$. Bu sonuç, üstbilişsel yazma stratejileri eğitiminin deney grubunun yazma becerisini olumlu yönde etkilediği şeklinde yorumlanabilir. Kontrol grubu verileri incelendiğinde, 
bağımlı gruplar t-testi sonucuna göre iki ölçüm arasında istatistiksel olarak anlamlı bir fark söz konusu değildir $\left[\mathrm{t}_{(29)}=.218, \mathrm{p}>.05\right]$. Üstbilişsel yazma stratejileri eğitiminin deney grubuna verildiği sürecin başlangıç ve bitişinde yapılan ölçümler dikkate alındığında, söz konusu süreç içerisinde, kontrol grubunun yazma becerisindeki başarı durumunda anlamlı bir farklılık meydana

Deney ve kontrol grubunda, deneysel işlem sonunda, öğrencilere yazdırılan ve kısaca ÖYBM olarak adlandırılan metinlerden elde edilen puanların normal dağılım gösterip göstermediği incelenmiştir. Gruplarının son ölçümlerinden elde edilen puanlara yönelik Shapiro-Wilk testi sonuçları Tablo 16'da verilmiştir:

Tablo 16. Deney ve Kontrol Gruplarında ÖYBM'den Elde Edilen Son Puanlarına İlişkin Shapiro-Wilk Testi Sonuçları

\begin{tabular}{llcccc}
\hline & Gruplar & $\mathbf{N}$ & $\overline{\mathbf{X}}$ & Ortanca & Shapiro-Wilk (p) \\
\hline \multirow{2}{*}{ ÖYBM } & Deney & 30 & 72.083 & 72.150 & $.001^{*}$ \\
& Kontrol & 30 & 66.043 & 65.850 & $.022^{*}$ \\
\hline
\end{tabular}

$* \mathrm{p}<.05$

Tablo 16'daki Shapiro-Wilk testi sonuçlarına göre, deney ve kontrol gruplarında ÖYBM'ye ait son ölçüm puanları normal dağılım göstermemiştir $(\mathrm{p}<.05)$. Bu nedenle, deney ve kontrol gruplarında ÖYBM'ye yönelik puanlar Tablo 17'de parametrik olmayan Mann-Whitney U testiyle karşıllaştırılmıştır:

Tablo 17. Deney ve Kontrol Gruplarında ÖYBM'ye İlişkin Son Ölçüm Puanlarının Karşılaştırılmasına Yönelik Mann-Whitney U Testi Sonuçları

\begin{tabular}{lccccc}
\hline Gruplar & N & Sira Ort. & Sira Top. & U & p \\
\hline Deney & 30 & 34.73 & 1042.00 & \multirow{2}{*}{323.000} & \multirow{2}{*}{060} \\
\cline { 1 - 4 } Kontrol & 30 & 26.27 & 788.00 & & \\
\hline
\end{tabular}

Tablo 17'deki Mann-Whitney U testine göre, deney ve kontrol gruplarının yazdığı bilgilendirici metinlere ilişkin son ölçüm puanları arasında oluşan farklılık istatistiksel olarak anlamlı değildir ( $U=323.0$; p> .05). Tablodaki sonuç, üstbilişsel yazma stratejileri eğitiminin olumlu etkisiyle deney grubu lehine oluşan puan farkının istatistiksel olarak anlamlı düzeye erişemediğini ifade etmektedir. Deney grubunun, kendisine ait ilk ve son ölçüm puanları arasında istatistiksel olarak anlamlı bir fark oluştuğu halde (bkz. Tablo 15), kontrol grubuyla karşılaştırıldığ 1 son ölçüm ortalamalarına göre istatistiksel olarak anlamlı bir fark ortaya çıkmamıştır. Tüm bu sonuçlar birlikte değerlendirildiğinde, üstbilişsel yazma stratejileri eğitiminin, deney grubundaki öğrencilerin grup içi ilk ve son ölçümlerinde yazma becerisi başarısında anlamlı düzeyde farklılık meydana getirdiği, deney grubuyla kontrol grubunun karşılaştırıldığ i ilk ve son ölçümlerde ise üstbilişsel yazma stratejileri eğitiminin 
deney grubunda yazma becerisini yeterli düzeyde iyileştiremediği sonucuna var1labilir.

\section{Deney Grubu Öğrencilerinin Deneysel İşlemle İlgili Görüşlerini Belirlemeye Yönelik Bulgu ve Yorumlar}

Üstbilişsel yazma stratejileri eğitiminin etkileri, öğrenci görüşleri doğrultusunda "düşünce ve tutuma etki", "yazma becerisine katkı", "yazma alışkanlığına katkı", "yazma kaygısına etki", "yazıya başlama duygusuna etki”" ve "üstbiliş stratejilerini kullanmaya etki" temalarına göre düzenlenmiştir. Her temanın altında öğrenci görüşleri tematik çerçevelere işlenmiştir.

Tablo 18. Üstbilişsel Yazma Stratejileri Eğitimine Yönelik Öğrenci Görüşleri

\begin{tabular}{|c|c|c|c|}
\hline Etki Kategorileri & & $\mathrm{n}$ & Katılımcılar \\
\hline \multirow{11}{*}{$\begin{array}{l}\text { ÜYSE'nin } \\
\text { düşünce } \\
\text { tutuma etkisi }\end{array}$} & $\begin{array}{l}\text { Daha güzel, istekli ve } \\
\text { özenli yazma }\end{array}$ & 8 & Ö1,Ö5,Ö10,Ö12,Ö19,Ö23,Ö24,Ö29 \\
\hline & Olumlu etkilenme & 5 & Ö3,Ö13,Ö17,Ö21,Ö27 \\
\hline & Daha iyi düşünme & 2 & Ö20,Ö22 \\
\hline & $\begin{array}{l}\text { Yazma hakkında bilgi } \\
\text { edinme }\end{array}$ & 2 & Ö5,Ö12 \\
\hline & Konuya odaklanma & 1 & Ö2 \\
\hline & Güzel cümle kurma & 1 & Ö25 \\
\hline & Yeteneğini keşfetme & 1 & Ö30 \\
\hline & Yazmayı önemseme & 1 & Ö18 \\
\hline & $\begin{array}{l}\text { Daha kolay konu } \\
\text { seçebilme }\end{array}$ & 1 & Ö1 \\
\hline & Özgüveni artırma & 1 & Ö5 \\
\hline & $\begin{array}{l}\text { Mevcut durumu } \\
\text { değiștirmeme }\end{array}$ & 2 & Ö7,Ö11 \\
\hline \multirow{8}{*}{$\begin{array}{l}\text { ÜYSE’nin } \\
\text { yazma } \\
\text { becerisine } \\
\text { katkıs1 }\end{array}$} & $\begin{array}{l}\text { Yazma becerisini } \\
\text { geliştirme }\end{array}$ & 10 & $\begin{array}{l}\text { Ö1,Ö11,Ö12,Ö13,Ö17,Ö19,Ö21 } \\
\text { Ö25,Ö27,Ö29 }\end{array}$ \\
\hline & $\begin{array}{l}\text { Yazmayla ilgili bilgiler } \\
\text { edinme }\end{array}$ & 2 & Ö3,Ö5 \\
\hline & $\begin{array}{l}\text { Yazıya nasıl } \\
\text { başlayacağını öğrenme }\end{array}$ & 2 & Ö7,Ö24 \\
\hline & $\begin{array}{l}\text { Çok yönlü bakmayı } \\
\text { sağlama }\end{array}$ & 2 & Ö18,Ö23 \\
\hline & $\begin{array}{l}\text { Yazmaya karşı ön } \\
\text { yargıları yıkma }\end{array}$ & 2 & Ö2,Ö20 \\
\hline & $\begin{array}{l}\text { Düşünerek ve dikkatli } \\
\text { yazma }\end{array}$ & 1 & Ö2 \\
\hline & $\begin{array}{l}\text { Kendini daha rahat ifade } \\
\text { etme }\end{array}$ & 1 & Ö10 \\
\hline & Zaman kaybi & 1 & Ö22 \\
\hline ÜYSE'nin & Daha sık yazma & 8 & Ö2,Ö3,Ö10,Ö12,Ö20,Ö25,Ö27,Ö29 \\
\hline
\end{tabular}




\begin{tabular}{|c|c|c|c|}
\hline $\begin{array}{l}\text { yazma } \\
\text { alışkanlığına } \\
\text { katkısı }\end{array}$ & $\begin{array}{l}\text { Olumlu etkilenme } \\
\text { Mevcut durumu } \\
\text { değiştirmeme }\end{array}$ & $\begin{array}{l}7 \\
5\end{array}$ & $\begin{array}{l}\text { Ö5,Ö18,Ö19,Ö21,Ö23,Ö25,Ö30 } \\
\text { Ö1,Ö7,Ö13,Ö22,Ö24, }\end{array}$ \\
\hline \multirow{2}{*}{$\begin{array}{l}\text { ÜYSE'nin } \\
\text { yazma } \\
\text { kaygısına etkisi }\end{array}$} & Kaygıyı azaltma & 15 & $\begin{array}{l}\text { Ö2,Ö3,Ö5,Ö10,Ö12,Ö13,Ö17,Ö18 } \\
\text { Ö19,Ö20,Ö23,Ö25,Ö27,Ö29,Ö30 }\end{array}$ \\
\hline & Etkili olmama & 6 & Ö1,Ö7,Ö11,Ö21,Ö22,Ö24 \\
\hline \multirow{3}{*}{$\begin{array}{l}\text { ÜYSE’nin } \\
\text { yazıya başlama } \\
\text { duygusuna } \\
\text { etkisi }\end{array}$} & $\begin{array}{l}\text { Keyifli ve severek } \\
\text { yazma }\end{array}$ & 12 & $\begin{array}{l}\text { Ö1,Ö2,Ö7,Ö12,Ö13,Ö17,Ö19, } \\
\text { Ö20,Ö22,Ö24,Ö25,Ö27 }\end{array}$ \\
\hline & $\begin{array}{l}\text { Özgüveni yüksek } \\
\text { hissetme }\end{array}$ & 6 & Ö3,Ö5,Ö18,Ö21,Ö29,Ö30 \\
\hline & $\begin{array}{l}\text { Güdülenme } \\
\text { Yazmayı sevmeme }\end{array}$ & $\begin{array}{l}2 \\
1\end{array}$ & $\begin{array}{l}\text { Ö10,Ö23 } \\
\text { Ö11 }\end{array}$ \\
\hline \multirow{3}{*}{$\begin{array}{l}\text { ÜYSE’nin } \\
\text { strateji } \\
\text { kullanımına } \\
\text { etkisi }\end{array}$} & $\begin{array}{l}\text { Öz değerlendirme } \\
\text { stratejileri }\end{array}$ & 8 & Ö3,Ö7,Ö10,Ö11,Ö19,Ö2 \\
\hline & Planlama stratejileri & 7 & Ö1,Ö13,Ö18,Ö21,Ö22,Ö24,Ö29 \\
\hline & $\begin{array}{l}\text { Kendini izleme } \\
\text { stratejileri }\end{array}$ & 6 & Ö2,Ö5,Ö12,Ö17,Ö25,Ö27 \\
\hline
\end{tabular}

ÜYSE: Üstbilişsel Yazma Stratejileri Eğitimi

Tablo 18'de üstbilişsel yazma stratejileri eğitiminin öğrencilerin mevcut düşünce yapısını ve yazmaya karşı tutumunu olumlu yönde etkilediği görülmektedir. Bu kategoride, katılımcılar tarafından en fazla ifade edilen görüş $(n=8)$, üstbilişsel yazma stratejileri eğitiminin eskiye göre daha güzel, istekli ve özenli yazmayı sağladığına ilişkin görüşlerdir. Öğrencilerden Ö1 bu durumu “...artık ilgimi çeken bir konu olursa daha istekli ve özenerek yazlyorum. Önceden yazı yazarken ilham gelmediği için yazma süreci sıkıntıl geçerdi...” şeklinde ifade etmiştir.

Öğrenci görüşlerinde; verilen eğitimin yazma sorunlarını gidermede yardımc1 olduğu, konuya odaklanmayı, bilgi ve özgüveni artırdığı, daha akıcı yazmaya ve daha iyi düşünmeye, yeteneğini keşfetmesine katkı sağladığı ve konu seçimini kolaylaştırdı ̆̆ dile getirilmiştir. Öğrencilerden Ö5, verilen eğitimle ilgili “...daha çok bilgi edindim. Özgüvenimi artırdl. Zaten severek yazan bir insandım. Şimdi daha düzgün yazmaya başladım. Hikâye ve benzeri metinler yazarken daha akıcı yazmaya başladım. Artık daha özenli yazıyorum." şeklinde görüş bildirmiştir. Verilen eğitimin etkisiz veya olumsuz olduğunu düşünen öğrenciler de $(\mathrm{n}=2)$ bulunmaktadır. Bu kategorideki öğrenciler verilen eğitimin düşünce ve tutumlarında herhangi bir değişiklik meydana getirmediğini söylemişlerdir.

Öğrencilerin önemli bir kısmı $(n=10)$ verilen eğitimin yazma becerilerini geliştirdiğini ifade etmişlerdir. Eğitim süreci, Ö12'nin görüşlerine "nasıl doğru yazabileceğimiz hakkında bilgiler verdi. Bu şekilde daha iyi yazılar yazmamıza yardım etti." biçiminde yansımış, deneysel işlemin "daha iyi yazı yazma" ya 
yardımcı olduğu belirtilmiştir. Üstbilişsel yazma stratejileri eğitiminin yazmayla ilgili bilgiler edinmede $(\mathrm{n}=2)$ öğrencilere katkı sağladığı görülmektedir. $\mathrm{Bu}$ katk1 Ö3 tarafından “...yazma hakkında pek bir bilgi sahibi değildim. Ama artık daha çok bilgi sahibi olduğum için metinleri daha mantıkl ve iyi yazmaya başladım." ş̧eklinde dile getirilmiştir. Ö5, verilen eğitimin yazma becerisi üzerindeki etkisini "çok fazla yazma bölümleri vard, yazdıkça yazım düzeldi. Metinlerde yazma hakkında bilgiler vardl. Bu bilgilerden de yararlanarak yazmayla ilgili daha çok bilgi edindim.” biçiminde değerlendirmiştir. Yazıya nasıl başlayacaklarını öğrenme $(n=2)$, yazarken çok yönlü bakma $(n=2)$, yazmaya karşı ön yargıları yıkma $(n=2)$, düşünerek ve dikkatli yazma ile kendini daha rahat ifade etme becerileri öğrencilerin deneysel süreçte edindikleri kazanımlardandır. Öte yandan bir öğrenci yapılan çalışmayı "zaman kaybı" olarak değerlendirmiştir.

Deneysel süreç sonunda görüşü alınan öğrencilerin önemli bir kısmı $(n=15)$ yazma alışkanlıklarının iyileştiğini belirten olumlu ifadeler kullanmıştır. Bununla birlikte, verilen eğitimin mevcut yazma alışkanlıkları üzerinde her hangi bir etkisi olmadığını söyleyen öğrenciler de vardır $(n=5)$. Öğrencilerin bir kısmı $(n=8)$ daha sık yazmaya başladığını, yazmaya daha fazla vakit ayırdığını ifade etmiş̧ir. Deneysel işlemin yazma alışkanlığına etkisi Ö3'ün görüşlerine "haftada bir önemli olaylarl günlügüume yazarken artı haftada iki kez yazıyorum.” şeklinde yansımıştır. Sözü edilen etki Ö10 tarafından “...her gece yatmadan önce günlük yazmaya başladım.” olarak ifade edilmiştir.

Öğrencilerin büyük çoğunluğu $(n=15)$ verilen eğitimin yazma kaygılarında azalma sağladığını ifade etmişlerdir. Ö12 deneysel işlemle ilgili olarak "Eskiden yazmadan önce kaygılanırken, artık nasıl yazacağımı bildiğim için daha az kaygılanıyorum." demiştir. Benzer biçimde Ö25 görüşlerini şöyle ifade etmiş̧tir: "Nasıl yazacağımı öğrendiğim için yazarken kaygılanmıyorum. Çünkü ben herhangi bir şeyi ögrendikten sonra o konu hakkında kaygılarım kayboluyor...”. Her iki öğrenci de yapılacak işin işlemsel bilgisine sahip olmanın, süreci kolaylaştırdığına işaret etmektedir.

Deneysel işlemden sonra öğrencilerin genel olarak yazıya olumlu duygularla başladığ̀ görülmektedir. Ö12 bu durumu "...çünkü artık nasıl yazacağımı biliyorum. Daha özgüvenli hissediyorum. Bu da severek yazmamı sağllyor.” biçiminde ifade etmiştir. Ö30 yazıya başlarken "...daha özgüvenli ve rahat" olduğunu belirtmiştir. Yazıya başlama duygusuyla ilgili ifade kategorilerinin tamamına yakını olumludur $(\mathrm{n}=20)$. Bu durumda üstbilişsel yazma stratejilerine yönelik eğitimin, öğrencilerin yazıya daha rahat başlamasına yüksek oranda etki ettiği söylenebilir. 
Öğrencilerin tamamı yazma sürecinde üstbilişsel yazma stratejilerinden birini kullandıklarını ifade etmişlerdir. Bu sonuç, öğrencilerin üstbilişsel yazma stratejilerini yeni görevlere transfer ettiklerini göstermektedir.

\section{SONUÇ, TARTIŞMA VE ÖNERILER}

Yazmak; zihni harekete geçirmek, sistemli bir biçimde düşünmek demektir. Yazma sürecinde, zihinsel boyutta gerçekleşen ve aslında gözlemlenemeyen karmaşık işlemleri sistematik bir yapıda görünür kılmak, başka bir ifadeyle düşünceyi metinleştirmek kolay değildir. Çünkü metin üretimi güçlü bir motivasyonun yanında bireyin ancak tecrübeyle kazanabildiği yaşam bilgilerini, okuma ve dinleme gibi alıcı dil becerileriyle elde ettiği birikimleri yerli yerinde kullanmayı gerektirir. Bunlara ilaveten doğru yazmak için strateji bilgisine de ihtiyaç vardır. Bu nedenle yazma işi Fransızca asıllı bir kelime olan ve "ayrı ayrı parçaları bir araya getirerek bir bütün oluşturma" (TDK, 2019) anlamına gelen kompozisyon terimiyle karşılanmaktadır.

Doğası gereği bilgi gerektiren, yoğun ve karmaşık süreçler içeren ve mutlaka bir düzen fikri taşıyan yazma işlemi, çoğu zaman öğrenciler tarafından kayg1 verici bulunmakta ve öğrencilerde yazmaya karş1 isteksizlik oluşabilmektedir. Yazma, bir beceriye dönüştügünnde ise güçlü bir iletişim aracına dönüşmektedir (Hallenbeck, 2002: 227). Yazma becerisi konusunda sözü edilen bu dönüşümün mümkün olduğunu gösteren birçok deneysel çalışma bulunmakta ve yazmanın geliştirilebilir bir beceri olduğu fikri literatürde yer almaktadır (Kantemir, 1991: 114; Karadağ ve Maden, 2014, 272; Karatay, 2015: 23). Bu çalışma da yazma becerisinin geliştirilebilir bir beceri olduğu fikrinden hareket etmekte, üstbilişsel stratejiler üzerinden yazma becerisine odaklanmaktadır.

Çalışmada; üstbilişsel strateji bilgisinin, öğrencilerin mevcut yazma becerisi seviyesine bir bileşen olarak eklendiğinde, yazma üretiminin gelişme sağlayıp sağlamayacağı ve yazmaya karşı olumlu bir tutumun geliştirilip geliştirilmeyeceği incelenmiştir. Çeşitli öğrenme farklılıkları ve öğrenme tarzları olan öğrencilerin, öğrenme sürecinin sorumluluğunu taşıma, karar verme, öğrenme sırasında zihinsel yeteneklerini kullanma gibi aktif öğrenme süreçlerinden geçmesi ve planlama, kendini izleme, öz değerlendirme yapma gibi üstbilişsel stratejileri kullanarak yazma becerisi alanında gelişme göstermesi çalışmanın temelini oluşturmaktadır. $\mathrm{Bu}$ çerçevede çalışmada, üstbilişsel yazma stratejilerine dayalı eğitimin yedinci sınıf öğrencilerinin üstbilişsel yazma stratejileri farkındalıklarına, yazma becerilerine ve yazmaya ilişskin tutumuna etkisi ele alınmıştır. Deneysel işlem olarak, öğrencilere on hafta boyunca uzaktan eğitim yoluyla üstbilişsel yazma stratejileri eğitimi verilmişsir. 
Üstbilişsel yazma stratejileri eğitiminin uygulandığı deney grubunda, öğrencilerin üstbilişsel yazma stratejilerine yönelik ön test ve son test puanları arasında son test lehine istatistiksel olarak anlaml farklılık bulunmuştur. Kontrol grubunda ise farklılık meydana gelmemiştir. Bu bulguya göre, üstbilişsel yazma stratejileri eğitimi yedinci sınıf öğrencilerinin üstbilişsel yazma stratejileri farkındalık düzeyini artırmada etkili olmuştur. Elde edilen sonuç, literatürdeki benzer çalışma sonuçlarıyla örtüşmektedir.

Negretti'nin (2009) öğrencilerin üstbilişsel farkındalığını araştırdığı çalışmasında, yazma stratejilerinin ve kişisel yazma süreçlerinin iyileştirilmesinde üstbilişsel farkındalığın kilit rol oynadığı belirlenmiştir. Negretti'nin (2012) diğer bir çalışmasında, öğrencilerin bir eğitim öğretim dönemi boyunca yazdıkları akademik metinler analiz edilmiş, üstbilişsel farkındalık ile öz düzenleme ve öğrencilerin bireysel yazma yaklaşımlarını geliştirme arasında ilişki tespit edilmiştir. Shabaya'nın (2004) çalışmasında, bazı öğretim stratejilerinin öğrencilerin üstbiliş becerilerini geliştirmeye yardımc1 olduğu, öğrencilerin bir yazar olarak öz algılarının olumlu yönde değiştiği ifade edilmiştir. Araştırma sonuçlarını destekleyen El-Hindi’nin (1994) çalışmasında, deney grubu hem okuma hem de yazma ile ilgili üstbilişsel beceri eğitimi almış, eğitim sonucunda katılımcılar üstbiliş açısından gelişim göstermişlerdir. "Martin (1987), üstbilişsel yazma eğitimi alan öğrencilerin geleneksel yazma eğitimi alan öğrencilere göre düşünce süreçlerinin daha çok farkında olduklarını tespit etmiştir."

Belirtilen araştırmalar üstbilişe dayalı strateji eğitiminin öğrencilerin üstbilişsel yazma stratejilerini kullanma düzeylerini olumlu yönde etkilediğini ortaya koymaktadır. Bu sonuçlara göre, üstbilişsel yazma stratejileri eğitiminin öğrencilerin strateji kullanma becerilerini geliştirici bir değişken olarak yazma çalışmalarında kullanılabileceği değerlendirilmektedir. Strateji eğitimini de öğrencilerin üstbilişsel farkındalık düzeyine katkı sağlayıcı bir süreç olarak yorumlamak mümkündür.

Üstbilişsel yazma stratejileri eğitiminin uygulandığı deney grubu ile MEB'in mevcut öğretim programı doğrultusunda eğitim yapılan kontrol grubu karşılaştırıldığında; son test puanlarına göre, üstbilişsel yazma stratejileri farkındalık düzeyinde deney grubu lehine istatistiksel olarak anlamlı farkl1lı bulunmuştur. Buna göre üstbilişsel yazma stratejileri eğitimi, öğrencilerin üstbilişsel yazma stratejileri fakındalıklarını artırmada MEB'in mevcut Türkçe öğretim programından daha etkili olmuştur. Geleneksel yöntemle ve herhangi bir müdahaleye maruz birakılmayan kontrol grubunun ön test verilerinden elde edilen sonuca benzer bir sonuç elde etmesi beklenen bir durumdur. Yine üstbilişsel yazma stratejileri eğitimi verilerek müdahale edilen deney grubunda, 
kontrol grubuna göre daha yüksek bir farkındalık ve puan ortalaması elde edilmesi literatürdeki benzer çalışmalarla tutarlık göstermektedir.

Şen'in (2003) deneysel çalışmasında, ilköğretim birinci kademe öğrencilerinin okuduğunu anlama düzeyleri ile üstbiliş stratejilerini kullanma arasında deney grubu lehine anlamlı fark bulunmuştur. Çakıroğlu ve Ataman (2008) üstbilişsel stratejilerin okuduğunu anlama düzeyi düşük öğrencilerde olumlu yönde etki yaptığını tespit etmiştir. Coşkun'un (2010) araştırmasında, üstbilişsel dinleme stratejilerine yönelik eğitim, deney grubunun dinleme performansında anlamlı düzeyde değişme sağlamıştır. "Melanlıŏlu'nun (2011), üstbiliş strateji eğitiminin dinleme becerilerini geliştirmeye etkisini incelediği çalışmasında deney grubu lehine anlamlı bir fark yakalanmıştır. Melanlığlu (2014), okuma eğitiminde üstbiliş stratejilerinden yararlanmanın okuma kaygısını azalttığını belirtmiştir. Katrancı (2012) deney ve kontrol gruplarındaki ögrencilerin üstbilişsel dinlediğini anlama farkındalığı arasında deney grubu lehine anlamlı bir fark olduğunu ifade etmiştir. Üstbilişsel okuma stratejileri öğretiminin okuduğunu anlama başarısına etkisini araştıran Duman ve Arsal (2015), öğrencilerinin üstbilişsel okuma stratejileri ile okuduğunu anlama başarıları arasında ilişki olduğunu belirtmişlerdir. Öztürk ve Uzunkol'un araştırmasında (2015), ilköğretim 4. sınıf öğrencilerinin okuma stratejileri üstbilişsel farkındalıkları ve okuma motivasyonları arasında pozitif yönlü ve anlamlı bir ilişki olduğu ortaya çıkmıştır. Üstbiliş stratejileri eğitiminin, ortaokul yedinci sınıf öğrencilerinin dinlediğini anlama becerileri üzerinde etkisini araştıran Harmankaya (2016), deneysel işlem sonrasında dinlediğini anlama becerileri açısından deney grubu lehine anlamlı bir fark yakalandığını belirlemiştir. Dinleme ve okuma becerileri ile ilgili olan bu araştırmaların ulaştığı sonuçlar ile çalışmamızda ulaşılan sonuçlar arasında tutarlık olduğu görülmektedir.”

Üstbilişsel yazma stratejileri eğitiminin uygulandığı deney grubunda, ögrencilerin yazmaya yönelik tutum düzeyi ön test ve son test puanları, son test lehine istatistiksel olarak anlamlı düzeyde farklılık göstermiştir. Deneysel işlem süresince MEB'in mevcut öğretim programı doğrultusunda eğitim yapılan kontrol grubunda ise anlamlı farklılık oluşmamıştır. Bu durumda, "üstbilişsel yazma stratejileri eğitimi öğrencilerin yazmaya yönelik tutumlarının iyileşmesinde etkili olmuştur. Deney ve kontrol grupları karşılaştırıldığında; yazmaya yönelik tutuma ilişkin son test puanlarının deney grubu lehine anlamlı düzeyde farklılaştığı anlaşılmıştır." Buna göre üstbilişsel yazma stratejileri eğitimi öğrencilerin yazmaya yönelik tutumlarının iyileşmesinde MEB'in programına göre daha etkili olmuştur. Ulaşılan sonuç, benzer araştırmalar tarafından desteklenmektedir. 
“Katrancı'nın (2012) üstbiliş stratejileri öğretiminin, ilköğretim beşinci sınıf öğrencilerinin dinlemeye yönelik tutumları üzerindeki etkisini araştıran çalışmasında, deney ve kontrol gruplarındaki öğrencilerin dinlemeye yönelik tutum erişileri arasında deney grubu lehine anlamlı bir fark olduğu tespit edilmiştir. Kıvrak'ın (2019) çalışmasında, üstbiliş stratejilerine dayalı dinleme etkinliklerinin öğrencilerin dinlediğini anlama becerisini geliştirdiği ve dinlemeye yönelik tutumlarını olumlu yönde etkilediği sonucuna varılmıştır. Meral (2019) yaptığı araştırmada, öğrencilerin üstbilişsel dinlediğini anlama farkındalık düzeyi ile dinlemeye ilişkin tutumları arasında yüksek ilişki tespit etmiştir."

Üstbilişsel yazma stratejileri eğitiminin uygulandığ öğrencilerin yazdığı bilgilendirici metinlere yönelik ilk ölçüm ile son ölçüm puanları dikkate alındığında, öğrencilerin yazma becerisi başarı düzeyinde son ölçüm lehine anlamlı düzeyde farklılık bulunmuştur. Kontrol grubunda ise bir farklılaşma gözlenmemiştir $\mathrm{Bu}$ bulguya göre üstbilişsel yazma stratejileri eğitimi öğrencilerin yazma becerisi başarı düzeyini artırmada etkili olmuştur. Deney ve kontrol grupları karşılaştırıldığında; iki grup arasında yazma becerisindeki başarı durumu istatistiksel olarak anlamlı düzeyde farklılık göstermemiştir. Üstbilişsel yazma stratejileri eğitimi deneysel işlemin başındaki başarı durumlarına oranla, deney grubundaki öğrencilerin yazma becerisi başarı düzeyinde etkili olmuştur; ancak MEB'in programı doğrultusunda eğitim gören kontrol grubuyla fark oluşturacak düzeyde deney grubunun üzerinde etkili olmamıştır. Ulaşılan sonuçların başka çalışmaların sonuçlarıyla benzerlik taşıdı̆̆ tespit edilmiştir.

Kaya ve Ateş'in (2016) öyküleyici metinleri esas alan çalışmasında, öyküleyici metin yazma becerilerinde deney grubu lehine istatistiksel olarak anlamlı bir farka ulaşılmıştır. Yurt içinde tespit edilebilen bir diğer çalışmada (Dülger, 2007), üstbiliş stratejilerine dayalı eğitim sonrasında yapılan ölçümde, yapılan müdahalenin deney grubu lehine yazma erişi ve kalıcılı̆̆ına katkıda bulunduğu sonucuna varılmıştır. Pitenoee, Modaberi ve Ardestani'nin (2017) bilişsel ve üstbilişsel yazma stratejilerinin orta öğretim öğrencilerinin yazı içeriklerini nasıl etkilediğini belirlemek için gerçekleştirdikleri deneysel çalışmada, strateji eğitimine tabi tutulan öğrenciler yazı içeriğinde daha iyi performans göstermiştir. Lv ve Chen'in (2010) çalışmaları üstbilişsel yazma stratejileri eğitiminin yazma becerileri üzerinde olumlu bir etkisi olduğunu göstermiştir. Davis (2009), Vygotsky'nin “yakınsal gelişim alanı” olarak bilinen kuramına dayalı olarak öğretmenlerin üstbiliş aracılığıyla öğrencilerin yazma becerisini nasıl geliştirdiğini ele almış, üstbiliş ile yazma hakkındaki bilgi birikiminin okul ve yaşam boyu öğrenme üzerinde etkisinin olduğu sonucuna varmıştır. Ward'ın çalışması (2009), üstbilişsel öğrenme stratejilerine dayanan öğretim sisteminin öğrencilerinin yazma başarısını etkilediğini göstermiştir. $\mathrm{Bu}$ 
çalışmadaki deneysel uygulamaya benzer biçimde, Darch'ın (2001) yaptığı çalışmada, Bruner'in destek sistemi adını verdiği iskele metaforunun yetenekli öğrencilerin hem üstbiliş hem de yazma becerilerini geliştirdiği görülmüştür. Sexton, Harris ve Graham (1998) tarafindan öğrenme güçlüğü çeken öğrencilerle üstbilişselliği içeren öz düzenlemeli strateji geliştirme modeli kullanılarak yürütülen çalışmalar, öğrencilerin yazma performansı ve yazma ile ilgili yaklaşımları üzerinde olumlu sonuçlar vermiştir. Sanchez-Villamil'in (1991) çalışmasında üstbilişsel stratejilerin yazma becerisinde önemli bir etkiye sahip olduğu sonucuna varılmıştır. Araştırmalar, üstbiliş stratejilerine yönelik deneysel işlemin öğrencilerin farkındalık düzeylerinde ve yazma becerileri başarı durumlarında olumlu etkiler yaptığını bildirmektedir. Dolayısıyla bu çalışmanın literatürdeki benzer çalışmalarla tutarlı sonuçlara ulaştığını söylemek mümkündür.

Araştırmanın nitel boyutunda, görüşü alınan öğrencilerin; \% 90,5'i yazma becerisi ile ilgili düşünce tutumunun, \% 95'i yazma becerilerinin ve yazıya başlama duygusunun, \% 75'i yazma alışkanlıklarının üstbilişsel yazma stratejileri eğitiminden olumlu yönde etkilediğini, \%71,4'ü yazma kaygılarında azalma olduğunu ifade etmişlerdir. Öğrenciler planlama, kendini izleme ve öz değerlendirme stratejilerini yazma süreçlerinde kullandıklarını da belirtmişlerdir. Araştırmanın sonuçları doğrultusunda şu öneriler sunulabilir:

1. Araştırmalar üstbilişin öğretilebilir bir beceri ve öğrenmenin güçlü bir yordayıcısı olduğunu göstermektedir. Üstbilişsel stratejiler; öğrenme sürecine yoğunlaşma, öğrenmeyi planlama, öğrenme görevini izleme ve kendi öğrenmesini değerlendirme gibi zihinsel beceriler içerir. $\mathrm{Bu}$ becerilerin gelişmesi için öğretmenlerin çeşitli öğrenme süreçlerini modellemesi, öğrencilere çoklu uygulama firsatı tanıması gerekir.

2. Üstbilişsel stratejilerin öğretilmesini esas alan bazı çalışmalar öğrenme güçlüğü çeken öğrencilere yöneliktir. Benzer şekilde, iş birlikli yaklaşımla öğrenme güçlüğü çeken öğrencilerin yazma becerileri geliştirilebilir.

3. Yazma becerisi için sınırlayıcı zamanlar verilerek görevin yerine getirilmesi yerine, görevin yerine getirilmesi için ihtiyaç duyulan zamanın verilmesi yazma kaygısını azaltabilir. Bu durumda, esas olan zaman değil, belirlenen ölçütlerdir.

4. Yurt dışındaki çalışmaların birçoğu, üstbiliş stratejilerinin daha çok ikinci dil öğretimindeki etkisine odaklanmaktadır. Türkçenin yabancı dil olarak öğretiminde üstbilişsel stratejilerin kullanımıyla ilgili araştırmalar yapılabilir.

5. Üstbiliş stratejileri, aslında işlemsel bilgi adı verilen bilgileri içerir. Planlama, izleme ve değerlendirmeye yönelik bilgiler bu kapsamdadır. 
Dolayısıyla bu çalışma işlemsel bilgilerin kazandırılmasına yönelik deneysel bir çalışma olarak da nitelendirilebilir. Benzer bir çalışma benlik bilgisi, dünya bilgisi, görev bilgisi ve strateji bilgisini içeren bildirimsel bilgiye dayandırılarak gerçekleştirilebilir.

6. Yedinci sınıf öğrencileriyle sınırlandırılan bu araştırma, farklı seviyedeki sınıflarla gerçekleştirilebilir.

7. $\mathrm{Bu}$ araştırma bilgilendirici metinlerle sınırlı tutulmuştur. Öyküleyici metinler için benzer bir araştırma yapılabilir. Elde edilecek sonuçlar bu çalışmanın sonuçlarıyla karşılaş̧ırılabilir.

\section{KAYNAKÇA}

Aydın, E. ve Kaya, M. (2021). Yazma yöntem ve teknikleri. (Ed. M. N. Kardaş). Yazma Ĕgitimi içinde, (ss. 181-214). Pegem Akademi.

Ayyıldı, M. ve Bozkurt, Ü. (2006). Edebiyat ve kompozisyon eğitiminde karş1laş1lan sorunlar. Türk Eğitim Bilimleri Dergisi, 4(1), 45-52.

Badger, R. and White, G. (2000). A process genre approach to teaching writing. ELT Journal, 54(2), 153-160. http://dx.doi.org/10.1093/elt/54.2.153

Bağcı, H. (2007). Türkçe öğretmeni adaylarının yazılı anlatıma ve yazılı anlatım derslerine yönelik tutumlarının değerlendirilmesi. TÜBAR-XXI-Bahar, 29-61.

Brandi, N. L. (2010). The influence of experiential and sociocultural factors on efficacy and instructional practices: four case studies of primary teachers of writing, [Unpublished doctoral dissertation]. The University of Akron.

Braten, I. (1991). Vygotsky as precursor to metacognitive theory: I. The concept of metacognition and its roots. Scandinavian Journal of Educational Research, 35(3), 179-192. http://dx.doi.org/10.1080/0031383910350302

Büyüköztürk, Ş. (2017). Sosyal bilimler için veri analizi el kitabl. Pegem Akademi.

Chamot, A. U. (2005). Language learning strategy instruction: current issues and research. Annual Review of Applied Linguistics, 25, (pp. 112-130). Cambridge University Press.https://doi.org/10.1017/S0267190505000061

Chamot, A. U. and O’Malley, J. M. (1987). The cognitive academic language learning approach: A bridge to the mainstream. TESOL Quarterly, 21(2), 227-249. https://doi.org/10.2307/3586733 
Coşkun, A. (2010). The effect of metacognitive strategy training on the listening performance of beginner students. Novitas-ROYAL (Research on Youth and Language), 2010, 4(1), 35-50.

Creswell, J. W. (2007). An introduction to mixed methods research. University of Nebraska-Lincoln.

Creswell, J. W. (2017). Araştırma deseni. Nitel, nicel ve karma yöntem yaklaşımları (Çev. Ed. S. Beşir Demir). Eğiten Kitap Yayınları.

Çakıroğlu, A. ve Ataman, A. (2008). Üstbilişsel strateji öğretiminin okuduğunu anlama başarı düzeyi düşük öğrencilerde erişi artırımına etkisi. Sakarya Üniversitesi Eğitim Fakültesi Dergisi, 16, 1-13.

Çokluk, Ö., Şekercioğlu, G. ve Büyüköztürk, Ş. (2018). Sosyal bilimler için çok değişkenli istatistik: SPSS ve LISREL uygulamalart. Pegem Akademi.

Darch, B. (2001). The role of scaffolding in providing the kinds of metacognition that may help more able key stage 3 pupils develop their writing abilities, [Unpublished doctoral dissertation]. The Open University.

Davis, B., J. (2009). A qualitative study of how writing is used in catholic secondary schools to foster students' metacognitive skill development. [Unpublished doctoral dissertation]. The University of San Francisco.

Duman, M. ve Arsal, Z. (2015). Türkçe dersinde bilişsel farkındalık okuma stratejileri öğretiminin etkililiği. Milli Ĕgitim Dergisi, 44(206), 5-15.

Dülger, O. (2007). The effect of metacognitive strategies on attitudes, achievement and retention in developing writing skills, [Yayımlanmamış doktora tezi]. Selçuk Üniversitesi.

El-Hindi, A. E. (1994). Relations between metacognition, reading and writing proficiency, and locus of control, [Unpublished doctoral dissertation]. The Graduate School Syracuse University.

Farahian, M. (2017). Developing and validating a metacognitive writing questionnaire for EFL learners. Issues in Educational Research, 27(4), 736-750.

Flower, L. and Hayes, J. R. (1980). Identifying the organization of writing processes.https://www.researchgate.net/profile/John_Hayes30/publicatio n/200772468_Identifying_the_organization_of_writing_processes/links/5 6784a4208ae125516ee7cc6.pdf. adresinden 5 Mart 2019'da alınmıştır. 
Flower, L. and Hayes, J. R. (1981). A cognitive process theory of writing. College Composition and Communication, 32(4), 365-387. https://doi.org/10.2307/356600

Göçer, A. (2010). Eğitim fakültesi öğrencilerinin yazılı anlatım becerilerinin süreç yaklaşımı ve metinsellik ölçütleri ekseninde değerlendirilmesi (Niğde Üniversitesi Örneği). Kastamonu Üniversitesi Kastamonu Eğitim Dergisi, 18(1), 271-290.

Güneş, F. (2011). Dil öğretim yaklaşımları ve Türkçe öğretimindeki uygulamalar. Mustafa Kemal Üniversitesi Sosyal Bilimler Enstitüsü Dergisi, 8(15), 123-148.

Hacker, D. J., Keener, M. C. and Kircher, J. C. (2009). Writing is applied metacognition. In D. J. Hacker, J. Dunlosky \& A. C. Graesser (Eds.), Handbook of metacognition in education (pp. 154-172). Routledge.

Hallenbeck, M. (2002). Taking charge: adolescents with learning disabilities assume responsibility for their own writing. Learning Disability Quarterly, 25(4), 227- 246. https://doi.org/10.2307\%2F1511355

Harmankaya, M. Ö. (2016). Üstbilişs stratejileri ĕgitiminin ortaokul ögrencilerinin dinlediğini anlama becerilerine, dinlemeye yönelik tutumlarına ve dinleme kaygılarına etkisi. [Yayımlanmamış yüksek lisans tezi]. Kırıkkale Üniversitesi.

Harten, M. D. (2014). An evaluation of the effectiveness of written reflection to improve high school students' writing and metacognitive knowledge and strategies, [Unpublished doctoral dissertation]. Boston University School of Education.

Hyland, K. (2016). Teaching and researching writing. Routledge.

Kantemir, E. (1997). Yazılı ve sözlü anlatım. Engin Yayınları.

Karadağ, Ö. ve Maden, S. (2014). Yazma eğitimi: kuram, uygulama, ölçme ve değerlendirme. (Ed. A. Güzel ve H. Karatay), Türkçe ögretimi el kitabı içinde (s. 265-306). Pegem Akademi.

Karatay, H. (2015). "Süreç temelli yazma modelleri: planlı yazma ve değerlendirme”, (Ed. M. Özbay), Yazma Eğitimi içinde (ss. 21-43). Pegem Akademi. 
Katranc1, M. (2012). Üstbilişs stratejileri öğretiminin dinlediğini anlama becerisine ve dinlemeye yönelik tutuma etkisi, [Yayımlanmamış doktora tezi] Hacettepe Üniversitesi.

Kaya, B. ve Ateş, S. (2016). Üstbilişsel beceri odaklı yazma süreçlerinin dördüncü sınıf öğrencilerinin hikâye yazma becerisine etkisi. Ĕgitim ve Bilim, 41(187), 137-164.

Kıvrak, S. (2019). Üstbilişs stratejilerine dayalı dinleme etkinliklerinin ilkokul dördüncü sinuf öğrencilerinin dinlediğini anlama becerilerine etkisi, [Yayımlanmamış yüksek lisans tezi]. Eskişehir Osmangazi Üniversitesi.

Kim, W-S. (1991). The role of metacognitive skills in young ESL student writing revision, [Unpublished doctoral dissertation]. University of Hawaii.

Lv, F. and Chen, H. (2010). A study of metacognitive-strategies-based writing instruction for vocational college students. English Language Teaching, 3(3), 136-144. http://dx.doi.org/10.5539/elt.v3n3p136

Martin, M. J. (1987). The effects of instruction in metacognitive strategies for composing on reading achievement and writing achievement, [Unpublished doctoral dissertation]. University of South Carolina.

Melanlığlu, D. (2011). Üstbilişs stratejileri eğitiminin ilköğretim ikinci kademe ögrencilerinin dinleme becerilerine etkisi, [Yayımlanmamış doktora tezi]. Gazi Üniversitesi.

Melanlıŏlu, D. (2014). Üstbiliş strateji eğitiminin ortaokul öğrencilerinin okuma kaygılarına etkisi. Eğitim ve Bilim, 39(176), 107-119.

Meral, E. (2019). İlkokul 4. sinıf ögrrencilerinin üstbilişsel dinlediğini anlama farkındalı̆̆ düzeyi ile dinlemeye ilişkin tutumlarl arasındaki ilişki, [Yayımlanmamış yüksek lisans tezi]. Adnan Menderes Üniversitesi.

Mills, B. (1953). Writing as process. College English, 15(1), 19-26.

Negretti, R. (2009). Metacognitive awareness in developmental writing students. [Unpublished doctoral dissertation]. The University of Hawai.

Negretti, R. (2012). Metacognition in student academic writing: A longitudinal study of metacognitive awareness and its relation to task perception, selfregulation, and evaluation of performance. Written Communication, 29(2), 142-179. https://doi.org/10.1177\%2F0741088312438529 
Özbay, M. ve Zorbaz, K. Z. (2012). İlköğretim ikinci kademe öğrencilerinin yazma tutukluğu düzeyi üzerine bir değerlendirme. Western Anatolia Journal of Educational Science. 3(5), 1-28.

Özden, M. Y. ve Durdu, L. (2016). Nitel araştırma yöntemleri. Anı Yayıncılık.

Öztürk, E. ve Uzunkol, E. (2015). İlköğretim 4. sınıf öğrencilerinin okuma stratejileri üstbilişsel farkındalıkları ve okuma motivasyonlarının değerlendirilmesi. Turkish Studies, 10 (7), 803-814.

Pressley, M. and Harris, K. R. (2008). Cognitive strategies instruction: From basic research to classroom instruction. The Journal of Education, 189(1/2), Theory, Research, Reflection on Teaching and Learning, 77-94. https://www.jstor.org/stable/42748661

Sallabaş, M. E. ve Temizkan, M. (2009). İlköğretim öğrencilerinin noktalama işaretlerini doğru olarak kullanabilme düzeyleri ile ilgili bir araştırma. Kastamonu Eğitim Dergisi, 17(2), 625-636.

Sanchez-Villamil, O. I. (1991). The effects of two metacognitive strategies on intermediate ESL college students' writing, [Unpublished doctoral dissertation]. Fordham University.

Scardamalia, M. (1984). Higher order abilities: written communication. American Educational Research Association, ERIC.

Schraw, G. and Moshman, D. (1995). Metacognitive theories. Educational Psychology Review, 7(4), 351-371.http://dx.doi.org/10.1007/BF02212307

Sexton, M., Harris, K. R., and Graham, S. (1998). Self-regulated strategy development and the writing process: effects on essay writing and attributions. Exceptional Children, 64 (3), 295-311.

https://doi.org/10.1177\%2F001440299806400301

Shabaya, J. (2004). The role of pre-service teachers in developing metacognitive awareness strategies among student writers in an urban high school english classroom, [Unpublished doctoral dissertation]. University of Akron.

Steinbach, J. C. (2008). The effect of metacognitive strategy instruction on writing, [Unpublished master thesis). University of Kentucky.

Şen, Ş. (2003). Biliş ötesi stratejilerin ilköğretim okulu beşinci sınıf ögrencilerinin okuduğuna anlama düzeylerine etkisi, [Yayımlanmamış doktora tezi]. Gazi Üniversitesi. 
Şimşek, R. ve Erdem, İ. (2021). Yabancı dil olarak Türkçe öğretiminde yazma becerisi ve kazanım ilişkisi. RumeliDE Dil ve Edebiyat Araştırmaları Dergisi, (22), 267-279. https://doi.org/10.29000/rumelide.895762

Tağa, T. ve Ünlü, S. (2013). Yazma eğitiminde karşılaşılan sorunlar üzerine bir inceleme. Turkish Studies, 8(8), 1285-1299. http://dx.doi.org/10.7827/TurkishStudies.5175

TDK (Türk Dil Kurumu), (2019). https://sozluk.gov.tr/

Tok, M. ve Ünlü, S. (2014). Yazma becerisi sorunlarının ilkokul, ortaokul ve lise öğretmenlerinin görüşleri doğrultusunda karşıllaştırılmalı olarak değerlendirilmesi. Elektronik Sosyal Bilimler Dergisi, 13(50), 73-95.

http://dx.doi.org/10.17755/esosder.04506

Ungan, S. (2007). Yazma becerisinin geliştirilmesi ve önemi. Erciyes Üniversitesi Sosyal Bilimler Enstitüsü Dergisi, 23(2), 461-472.

Ülper, H. (2008). Bilişsel süreç modeline göre hazırlanan yazma ögrretim programının ögrenci başarısına etkisi, [Yayımlanmamış yüksek lisans tezi]. Ankara Üniversitesi.

Ward, N., B. (2009). The influence of a metacognitive learning system on the writing achievement of elementary school students, [Unpublished doctoral dissertation]. Seton Hall University.

Vanderburg, R. M. (2006). Reviewing research on teaching writing based on Vygotsky's theories: what we can learn. Reading \& Writing Quarterly, 22, 375-393. https://doi.org/10.1080/10573560500455778

Velzen, V. J. (2016). Metacognitive learning advancing learning by developing general knowledge of the learning process. Springer International Publishing.

Yıldırım, A. ve Şimşek, H. (2018). Sosyal bilimlerde nitel araştırma yöntemleri. Seçkin Yayıncılık.

Yi, J. Y. (2006). Construction of a rating scale for writing assessment in an EFL context, [Unpublished doctoral dissertation]. The University of Edinburgh.

Zamel, V. (1982). Writing: the process of discovering meaning. TESOL Quarterly, 16(2), 195-209, 195-209. https://doi.org/10.2307/3586792 